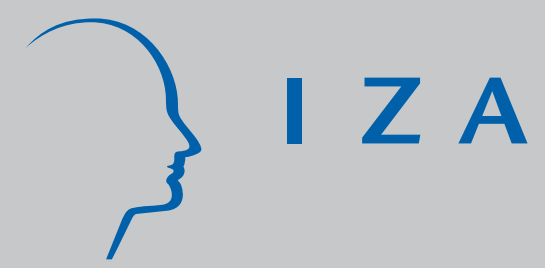

IZA DP No. 8600

Reemployment and Substitution Effects from Increased Activation: Evidence from Times of Crisis

Pedro S. Martins

Sofia Pessoa e Costa

October 2014 


\title{
Reemployment and Substitution Effects from Increased Activation: Evidence from Times of Crisis
}

\author{
Pedro S. Martins \\ Queen Mary University of London, \\ CEG-IST and IZA \\ Sofia Pessoa e Costa \\ Université catholique de Louvain \\ and CGR-QMUL
}

\section{Discussion Paper No. 8600 \\ October 2014}

IZA

\author{
P.O. Box 7240 \\ 53072 Bonn \\ Germany
}

\author{
Phone: +49-228-3894-0 \\ Fax: +49-228-3894-180 \\ E-mail: iza@iza.org
}

\begin{abstract}
Any opinions expressed here are those of the author(s) and not those of IZA. Research published in this series may include views on policy, but the institute itself takes no institutional policy positions. The IZA research network is committed to the IZA Guiding Principles of Research Integrity.

The Institute for the Study of Labor (IZA) in Bonn is a local and virtual international research center and a place of communication between science, politics and business. IZA is an independent nonprofit organization supported by Deutsche Post Foundation. The center is associated with the University of Bonn and offers a stimulating research environment through its international network, workshops and conferences, data service, project support, research visits and doctoral program. IZA engages in (i) original and internationally competitive research in all fields of labor economics, (ii) development of policy concepts, and (iii) dissemination of research results and concepts to the interested public.
\end{abstract}

IZA Discussion Papers often represent preliminary work and are circulated to encourage discussion. Citation of such a paper should account for its provisional character. A revised version may be available directly from the author. 


\title{
ABSTRACT
}

\section{Reemployment and Substitution Effects from Increased Activation: Evidence from Times of Crisis}

\begin{abstract}
Although activation services such as monitoring, training, or job subsidies have been shown to increase exits from unemployment, there is little comprehensive evidence about the effects of activation during recessions. Here we evaluate a large activation programme introduced in Portugal in 2012, a time of very high unemployment. This programme required specific unemployment benefit recipients to meet jobcentre caseworkers and then participate in active labour market policies. Our analysis draws on rich longitudinal data, the programme's focus on those unemployed for at least six months, and fuzzy regression discontinuity methods. We find that, despite the weak labour market, the programme is very successful as it doubles the monthly reemployment probability. The results are robust to a number of checks, including a falsification exercise based on pre-programme data and an analysis of non-employment and income effects. Moreover, in a novel IV approach using information on all unemployed, we find no evidence of substitution effects such as decreased transitions to employment amongst non-eligible individuals.
\end{abstract}

JEL Classification: J64, J68, J22

Keywords: public employment services, job search, public policy evaluation

Corresponding author:

Pedro S. Martins

School of Business and Management

Queen Mary, University of London

Mile End Road

London E1 4NS

United Kingdom

E-mail: p.martins@qmul.ac.uk

\footnotetext{
* We thank comments from Torben Andersen, Erich Battistin, Patricia Borges, Michael Lechner, Domingos Lopes, Giulia Santangelo, Arne Uhlendorff and seminar participants at Nova School of Business and Economics, Queen Mary University of London, the European Commission, the Bundesbank, Maynooth University, PEJ (University of Minho) and St Gallen University. We also thank financial support from the European Union under the 'ActiValuate: Counterfactual impact evaluation of a large activation programme' project (DG Employment, Social Affairs and Inclusion, European Commission) and research assistance from Mariana Tavares. Part of this paper was written at Nova SBE, whose hospitality is greatly appreciated. We are also grateful for data access provided by the Ministry of the Economy and Employment, Portugal. Sole responsibility lies with the authors and the European Commission is not responsible for any use that may be made of the information contained herein.
} 


\section{Introduction}

The current high levels of unemployment across many countries, following the 2008 financial crisis, raise considerable interest on the relative merits and potential of activation programmes (OECD 2013). These programmes involve a number of measures, typically led by public employment services, directed towards reducing the length of a joblessness spell, such as counselling, training, workfare, monitoring or sanctions (OECD 2007). Nevertheless, although several studies have evaluated activation programmes across different countries and time periods, the literature - which we review in the next section - does not include, to the best of our knowledge, any analysis of such interventions implemented during periods of high unemployment.

However, it is particularly important to assess activation programmes during such times of crisis. Indeed, there is a pressing need, at such times, for policies that may deliver results relatively quickly in terms of reducing or, at least, containing unemployment. Moreover, from a theoretical perspective, it is unclear whether activation is more or less effective at such times. On the one hand, economic downturns may be exactly when the benefits from activation efforts, namely in terms of enhanced reemployment, are at their weakest. This follows from the diminished number of vacancies available and the greater competition for them from the larger pool of job applicants, increasing the scope for displacement effects (Crépon et al. 2013). On the other hand, activation may have a greater reemployment impact during recessions if the unemployed focus more on formal job search at those times van den Berg \& van der Klaauw 2006), to the extent that activation tends to be more directed towards formal than informal job search. Lock-in effects may also be less relevant during recessions, as employment alternatives to training are scarcer (Lechner \& Wunsch 2009).

Findings regarding the effects of activation programmes during periods of downturn are also relevant from the perspective of the on-going policy debate in the European Union and elsewhere on the relative merits of structural reforms and aggregate demand expansion. Similarly, the major new European Union (2013) initiative establishing a 'Youth Guarantee', whereby all those aged below 25 are to obtain a job, training or education offer over the first four months of their unemployment spell, can also be informed by such findings.

This paper addresses this major gap in the external validity of the activation literature by evaluating a large programme implemented in Portugal in early 2012. This is a country and 
time period when unemployment reached unprecedented levels: the unemployment rate was $14.9 \%$ in the first quarter of 2012 , having increased from $7.6 \%$ in the same quarter of 2008 . Moreover, the increase in unemployment was largely driven by low hirings, caused by a 'perfect storm' of austerity measures, economic uncertainty, financial deleveraging, weakened external demand, high and pervasive minimum wages and downward wage rigidities. Such extreme economic environment, prompting a substantially weakened labour demand, particularly in terms of new hires, interacted with relatively generous unemployment benefits (UBs) and other unfavourable institutional labour-market aspects (described later), made the public employment service activation efforts studied here particularly challenging.

The programme we evaluate, Convocatórias, was based on requiring that certain groups of unemployed individuals participate in meetings in jobcentres. Following the meetings, and depending on the specific individual assessment conducted by their caseworkers, including further monitoring of the job search efforts, the targeted unemployed would be directed towards active labour market measures, including counselling, traineeships, job subsidies, training, or workfare. Some unemployed would also be directed towards job interviews, if good matches with available vacancies were found. The introduction of Convocatórias also corresponded to a shift in the activation work of the public employment service, towards greater effort targeted at those registered with the public employment service for longer periods of time, including unemployment benefits recipients (UBRs, henceforth).

As indicated above, and crucially for identification purposes, the programme was targeted at specific groups of unemployed individuals. These groups were the UBRs of a certain age range (45 or above) or of a certain unemployment benefit (UB) duration range (six months or more). These criteria establish clear differences in programme eligibility across UB duration levels, which we explore through a fuzzy regression discontinuity approach $($ Lee \& Lemieux 2010). In particular, in this paper we focus on those aged 44 or less that are targeted exclusively by the UB duration criteria. We then study the effects of the programme in terms of reemployment and other outcome variables on UBRs unemployed for six months or more in comparison with UBRs employed for less than six months.

The empirical analysis draws on two detailed administrative data sets, each one including longitudinal individual information on the population of those unemployed over the first twelve months of the programme. The first data set is drawn from the records of the Portuguese 
public employment service and includes information such as the date of registration in the jobcentre and the date when the unemployed was subject to the Convocatórias programme (if applicable), as well as several background variables. The second data set is based on social security information and includes records on the employment status, salaries and UBs of each individual in each month. After merging the two data sets, we follow individuals as they are unemployed, subject or not to the Convocatórias intervention, and eventually return to employment.

Our results indicate that the increased activation efforts delivered by the programme had large positive effects in terms of reemployment. This is an important result, particularly given the challenging economic and labour market conditions and the relatively light nature of the intervention. In fact, the estimates imply a doubling of the probability of next-month reemployment for those subject to the programme. The effects estimated are typically of at least $4 \%$, a percentage that exceeds the average monthly reemployment probability over the relevant unemployment duration range. These findings are also found to be robust to a large number of checks, including the analysis of different subsamples of unemployed individuals and a falsification exercise based on pre-programme social security data.

Moreover, we draw on our coverage of all the unemployed registered in jobcentres, including those not entitled to UBs, to assess the magnitude of any substitution or displacement effects. In this case, some or all of the reemployment effects would come at the cost of fewer transitions amongst non-eligible unemployed. However, we find no evidence of decreased transitions to employment amongst non-eligible unemployed, even when instrumenting the outflows of the target unemployed groups using information on the number of Convocatórias interventions across jobcentres over time.

The structure of the paper is as follows: The next section provides a review of activation practices and of the literature on the impact of activation programmes. Section 3 describes the activation programme and its context, namely in terms of labour market institutions. Section 4 presents the data sets and their descriptive statistics while the econometric model is introduced in Section 5. The reemployment and substitution results are presented in Sections 6 and 7 . Finally, Section 8 concludes. 


\section{Activation practices and programmes}

Many countries have implemented activation strategies aimed at increasing work incentives and opportunities for UBRs and other unemployed individuals. These can be particularly important not only in terms of addressing moral hazard issues but also to foster effective lifelong learning perspectives. These activation strategies are generally two-fold, including monitoring and sanction procedures, as well as ALMPs, counselling and job search assistance. Moreover, their implementation procedures tend to exhibit a considerable deal of diversity across countries, including in terms of an 'extensive margin' regarding the number or percentage of unemployed that are interviewed in jobcentres and an 'intensive margin' concerning the extent to which such initial interviews, which typically involve lighter interventions, then lead to further involvement in ALMPs, such as training or workfare.

To shed light on these aspects, we present a summary of their characteristics across eight countries, based on OECD (2007), in Tables A.2 and A.3. We consider several dimensions of such procedures, including placement efforts at initial registration, frequency of reporting, use of direct referrals, collective information sessions and job search verification during participation. Across the eight countries considered, the differences in activation practices appear to be particularly important in terms of 'Services provided by the Public Employment Service' and 'Participation in ALMPs'. These differences raise external validity questions regarding the extent to which the results from activation studies can be expected to hold in different countries. Indeed, such and other institutional aspects, including the generosity of the UBs, can interact powerfully with activation efforts.

In most countries considered, the public employment service (PES, henceforth) uses direct referrals to help the unemployed re-enter the labour market, although there is variation on the average number of direct referrals, as well as on who reports on application outcomes. There are also important differences on how the PES engages with the unemployed, namely in terms of the frequency of interviews (some countries do not have a specific timing defined, others meet with the unemployed fortnightly), in terms of collective information sessions and in terms of individual action plans (in some countries the action plan is written up after one week to one month of unemployment while in other countries only after nine months). Participation in ALMPs tends to be compulsory in most countries although job search requirements may not be imposed during such periods. 
From a theoretical perspective on activation, in particular in the context of job search models, activation programmes may increase the cost of being unemployed, leading the unemployed to increase their job search and or decrease their reservation wages, leading to an increase in transitions out of unemployment 1 This is indeed the result most commonly found in the literature that conducts evaluations of specific activation programmes, as we explain below and summarise in Table A.1.

Despite the general finding of an increase in transitions out of unemployment from activation programmes, there is not a consensus on the typical destination state. One strand of the literature finds that the increase in transitions out of unemployment is accompanied by an increase in transitions to employment. For instance, Graversen \& van Ours (2008) study a mandatory experimental activation programme in Denmark. They find that unemployment duration decreases by 2.5 weeks (compared to a median of 11.5 weeks) and transitions to employment increase by 30\%. Graversen \& van Ours (2008) justify these large effects with programme duration and intensity, which involves several steps: first, a notification letter; second, participation in a job search programme; and third, participation in an ALMP. Indeed, during the job search stage, the unemployed attend weekly or fortnightly meetings with caseworkers where they receive counselling, are referred to job offers and have their job search efforts monitored.

Klepinger et al. (2002) study the impact of tighter search requirements (a doubling of the standard number of employer contacts per month), monitoring (verification of work-search contacts) and counselling (participation in a job search workshop) on total UB paid and UB duration based on a 1994 experiment in Maryland. They find that both more demanding search requirements and monitoring lead to a decrease of around $6 \%$ in UB payments and a decrease of between 6 and $7 \%$ in the number of weeks on UB. Counselling also reduces UB payments and unemployment duration. Klepinger et al. (2002) also study the impact on employment and earnings and find little impact on both. Similar results were found for other countries, namely the UK (Dolton \& O'Neill 2002) and Australia (Borland \& Tseng 2007).

In another interesting study, McVicar (2008) evaluates the impact of a complete interruption in monitoring, when activation was suspended for exogenous reasons in different parts of Northern Ireland and for different periods between 1999 and 2005. The results indicate

\footnotetext{
${ }^{1}$ See Cockx et al. (2014) for a theoretical analysis of the welfare effects of job search requirements, in particular of the extent to which procrastination may make such requirements Pareto improving.
} 
that a total lack of monitoring leads to an important decrease in transitions out of unemployment, mainly explained by a decrease of transitions to employment. Several other studies also find positive effects of activation programmes on transitions to employment (van den Berg \begin{tabular}{l|l|l|l|l|}
\hline et al. 2004, Geerdsen 2006, Boone et al. 2009, Cockx \& Dejemeppe 2012), including van den \\
\hline
\end{tabular} Berg et al. (2012) who find further positive effects of jobcentre meetings with caseworkers in Denmark.

Another strand of the literature finds that the increase in transitions out of unemployment leads to an increase in transitions to other benefits or non-subsidised unemployment, but not employment. It is the case of Manning (2009), which evaluates the effect of the job seekers allowance (JSA) in 1996, using a differences-in-differences approach. He finds that the tightening of job search requirements, as imposed at that time, can prompt some of the unemployed to lower their search intensity and move out of subsidised unemployment altogether, particularly if their previous search intensity was already low (and when UBs are relatively low). Manning (2009) finds that the JSA reform led to a decrease of around $8 \%$ in the number of subsidised unemployed, almost completely explained by the increase in transitions to non-subsidised unemployment. When considering the impact of the JSA introduction not only on transitions out of unemployment but also future earnings and weeks worked, Petrongolo (2009) finds an increase in the former and a decrease in the latter two variables. These results can be explained by a decrease in reservation wages in the context of a job search model, leading the unemployed to accept lower-quality jobs.

Other studies, as well as some of those mentioned above, find evidence of 'threat' effects: future participation in a programme increases the perceived cost of being unemployed, leading to an increase in transitions out of unemployment even before participation takes place $(\overline{B l a c k}$

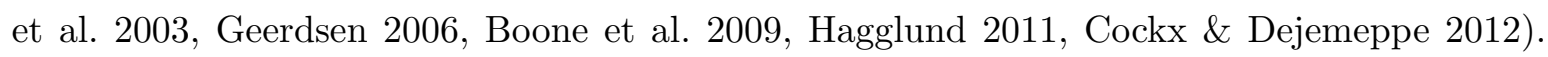
For example, Cockx \& Dejemeppe (2012) evaluate the impact of a notification letter sent to the unemployed in Belgium to inform them of the implementation of a new monitoring policy. They find that transitions to employment increase by nine percentage points, even without further contacts between the unemployed and the public employment services.

One additional important aspect is that all articles above study the impact of activation programmes in countries and time periods when the business cycle is at a relatively normal level. However, the economic climate can interact powerfully with the outcome of a pro- 
gramme. For instance, van den Berg \& van der Klaauw (2006) present a job search model with both formal and informal search and show that the impact of activation strategies, namely monitoring, on transitions to employment should be larger the worse the (individual or aggregate) labour market prospects: in the case of a declining labour market, the unemployed will tend to rely extensively on formal search, which is more sensitive to monitoring than informal search. Using a 1998 natural experiment in the Netherlands, van den Berg \& van der Klaauw (2006) find that both the older and the longer-term unemployed benefit more from counselling and monitoring. These results are consistent with the perspective that the effects of activation are stronger the worse the labour market prospects of the unemployed. Another paper that relates programme participation with the economic climate is Lechner \& Wunsch (2009), which studies the impact of training in times of relatively high unemployment. They find larger positive long-term effects when unemployment is high. They offer two explanations for this result. One is that the positive effects of increased human capital from participation dominate the negative 'lock-in' effects in downturns. The other is that programme participation during periods of high unemployment avoids unfavorable job matches that can have negative impacts in future labour outcomes.

The results presented previously generally do not take into account the possible presence of substitution (or displacement) effects, which occur when positive outcomes for programme participants are obtained at the expense of negative outcomes for non-participants. In other words, displacement effects may occur if participants take jobs that non-participants would otherwise get, with little or no aggregate effect. One of the very few studies that examines such effects is Blundell et al. (2004), who evaluate the impact of the UK New Deal for Young People (NDYP) in terms of transitions to employment. The NDYP was first implemented in pilot areas and afterwards rolled out across the UK. The treatment group considered in Blundell et al. (2004) are the unemployed aged 19-24 in pilot areas and the control group are the unemployed of the same age but based in non-pilot areas. After finding positive effects of the programme of around 20\%, Blundell et al. (2004) check for displacement effects by comparing transitions to employment between the treatment group and a group of non-eligible older (2530 years old) unemployed individuals but otherwise very similar, and also based in pilot areas. The case for displacement effects is not supported given that the treatment effect obtained under this second analysis is not larger than the effect obtained in the main analysis. 
The only other article that we know of that considers displacements effects is Crépon et al. (2013) who find positive effects for an assistance programme for college-educated unemployed youth in France. However, these positive results are non-lasting and obtained partly at the expense of non-treated workers, especially in the case of weak regional labour markets, where there are many unemployed competing for a relatively small number of job vacancies.

Overall, the literature that evaluates activation programmes tends to find that these have significant effects in terms of unemployment exits and sometimes also in terms of reemployment. These effects can be driven by a threat element, which tends to be associated with informal jobs, especially when UBs are relatively generous. As indicated above, all findings so far refer to economic environments characterised by relatively low unemployment rates, an important gap in terms of the external validity of the literature that our paper addresses.

\section{The Convocatórias programme and its context}

\subsection{The Portuguese labour market}

As indicated above, the Convocatórias programme was implemented in Portugal in 2012, a year when the country was immersed in an economic and financial crisis, with heavy consequences in terms of unemployment growth and lack of job creation. In fact, the unemployment rate in Portugal increased steadily since the first quarter of 2008 until the first quarter of 2013, from $7.6 \%$ to $17.4 \%$, having since then decreased to $14.4 \%$ (second quarter of 2014). During the time frame of our study, from February 2012 to February 2013, the quarterly unemployment rate rose from $14.7 \%$ to $17.4 \%$. These rates are at least twice as large as the average of the rates prevailing at the times of the other programmes we survey in Table A.1 and at least four percentage points larger than the highest rate over those fourteen studies $(8.6 \%$ in Australia in 1997-98).

Another important aspect concerns the proportion of long-term unemployed (those unemployed for 12 months or more), which was relatively stable at around $50 \%$ during 2011 and the first quarter of 2012, but then increased to close to $60 \%$ in the first quarter of 2013 . Moreover, the overall number of UBRs (including also means-tested unemployment assistance, which amounts to about $20 \%$ of the total) peaked at 421,000 in April 2013, from a lowest level over the cycle of 243,000 in July 2008, reaching 361,000 in March 2012, when Convocatórias was launched. A related indicator of the severity of the crisis is the number of job vacancies 
available in the PES. Although these are only a subset of approximately $10 \%$ of actual vacancies, PES vacancies dropped significantly too, by $30 \%$ or more from 2011 to 2012, when they reached a figure of approximately 5,000 per month.

In terms of the institutional framework surrounding the labour market, UBs can be characterized as relatively generous in their replacement rates and maximum durations but restrictive in terms of their coverage of the unemployed. First, the general replacement ratio is $65 \%$ in gross terms and $75 \%$ in net terms, although the latter figure increases to about $100 \%$ for low-wage workers. Second, benefit entitlement periods range between 9 and 38 months, depending on age and prior labour market attachment, excluding the means-tested unemployment assistance provisions, which are available for between half and the same period as UB. Third, coverage is restricted to those that worked at least 15 months over the previous 24 months and that lose their jobs involuntarily (or whose fixed term contracts expire).

One should note that in March 2012, shortly after the Convocatórias programme was introduced, some changes were made to UBs. However, these changes are applicable only to individuals that become unemployed once the new law came into force, in April 1st. These changes consisted in wider access (from a minimum of 15 to 12 months of work over the previous 24 months), shortened maximum durations (but only for those who had not worked at least 15 months by March 2012), and a $10 \%$ cut in the UB amount after six months.

Concerning activation requirements and practices, all UBRs are required to register in their local jobcentre. Registration establishes a number of duties that the UBR must carry out, including availability for any ALMPs indicated by the jobcentre and a given minimum number of job applications every month. UBRs also have to accept to interview for vacancies that the jobcentre deems appropriate (and which pay a salary similar or higher to the one the UBR earned before becoming unemployed). Moreover, UBRs are required to present themselves every fortnight at their local council (or jobcentre) to confirm their status as unemployed. Should the jobcentre consider that the UBR is not complying with its obligations, the jobcentre may deregister the UBR, implying that the UB will be cut entirely. In practice, the extreme severity of the penalty implies that it is rarely applied (OECD 2012). Moreover, the fortnightly attendance check, typically at a local council, also adds little value in terms of activation as it typically does not involve job search monitoring or other activation services. See also Tables A.3 and A.3 for a comparison of job search requirements in terms of the fre- 
quency of reporting, which is typically more intensive in the other countries considered than in Portugal.

As to other relevant labour market institutions, employment protection legislation is also regarded as strict, despite recent reforms in the context of the 2011-2014 economic and financial adjustment programme:2 Moreover, the minimum wage covers a relatively large share of workers, over $10 \%$ in 2012 , and amounts to approximately $60 \%$ of the median wage. Furthermore, the Portuguese labour law also establishes that base wages cannot be adjusted downward, even in low inflation environments, except in very specific circumstances. On top of that, the extension of virtually all collective bargaining agreements to non-affiliated firms and workers up to mid-2011 created a large number of binding minimum wages for most occupations and job levels across all sectors Martins (2014a).

Overall, from an institutional perspective, the employment and social security laws and practices create strict constraints that tend to result in lower hirings and higher levels of long-term unemployment. Moreover, the activation practices conducted by the PES up to the introduction of the Convocatórias programme were also relatively superficial, especially as far as the UBRs were concerned, and particularly given the relative generosity of UB. This context creates considerable scope for the observed typical long spells of unemployment (Portugal \& Addison 2008, Addison \& Portugal 2008) and their well-known negative impact upon human capital and future employability.

\subsection{The Convocatórias programme}

In March 2012, the Portuguese government launched an action plan aimed at the modernization of the PES $\left.\right|^{3}$ This action plan included a number of measures, most of which directed towards a greater activation of the unemployed.

The programme studied in this paper, Convocatórias, is one of such measures. The programme is based on the requirement that the Portuguese PES (IEFP, Instituto do Emprego e Formação Profissional) calls up all UBRs of specific profiles for meetings with caseworkers in jobcentres. Moreover, the programme allows jobcentres to establish the content of the

\footnotetext{
${ }^{2}$ See OECD (2012) for international comparisons in several indicators and Martins (2014b) for more information on this and other labour market reforms introduced between 2011 and 2013 in Portugal. Fixed-term contracts, unlike their permanent counterparts, are not regarded as restrictive and are also the most common form of outflow from unemployment.

${ }^{3}$ This initiative, the 'Public Employment Service Relaunch Programme', was established by the Council of Ministers Resolution 20/2012, of March 9th, available at http://dre.pt/pdf1sdip/2012/03/05000/0105901061.pdf (in Portuguese).
} 
meeting and their follow-up, subject to the broad guidelines that the PES should take actions that can activate UBRs and increase their rates of transition to employment. In terms of the terminology we introduced in Section 2, Convocatórias strengthened both the extensive and intensive margins of activation, by widening the range of UBRs subject to jobcentre meetings and by increasing their involvement in ALMPs, respectively.

In practical terms, the content of the initial meetings and their follow-up actions were varied, depending on the specific profile of each unemployed individual. In general, the jobcentres monitored the jobsearch effort exerted by the UBR and updated their records regarding the profile of the UBR with a view to facilitating matches with available vacancies. In several occasions, the UBR's personal employment plan, which sets requirements such as a minimum number of monthly job applications to be sent by each person, were also updated. Moreover, depending on the specific profile of each individual, the jobcentre would conduct a number of additional actions. These included jobsearch counselling, job interviews participation requirements, training, self-employment support, and workfare or traineeship placements.

An additional important aspect concerns the UBR profiles targeted by the programme. Two specific groups were considered, namely UBRs aged 45 or older, and UBRs unemployed for at least six months. These two groups were seen to be of greater interest in terms of a more intense activation work to be delivered by the PES. Moreover, from an operational perspective, the Convocatórias programme was implemented gradually, given capacity restrictions across jobcentres, in some cases also involving a greater priority to meetings with UBRs of lower schooling levels. In this paper, we focus exclusively on the second group (subsidised unemployment spells of six or more months), in particular UBRs with unemployment spells of between 1 and 12 months and not older than 44. The latter restriction ensures that we focus exclusively on the UBRs only subject to the six-month stream of Convocatórias. The group of unemployed aged 45 or older is more challenging to examine, at least based on a regression discontinuity approach as the one used here, given that the unemployed that register when they are 45 or older are typically entitled to longer unemployment benefit provision.

Another relevant aspect is the introduction of a wage subsidy, also in the context of the PES action plan mentioned above. This wage subsidy, Estímulo 2012, was targeted exclusively at those unemployed for at least six months, although including both those entitled or not to $\mathrm{UB}, 4$ In any case, this measure reinforced the range of active labour market policies that

\footnotetext{
${ }^{4}$ This measure was established by the Executive Order 45/2012, of February 13th, available at
} 
could be used under Convocatórias and therefore increased the scope for additional activation further to the jobcentre meetings.

Overall, the Convocatórias programme introduced an important strengthening of the activation efforts delivered by the Portuguese PES towards the UBRs and the long-term unemployed, involving over 240,000 individuals over its first year of operation. Moreover, the concurrent introduction of Convocatórias and Estímulo 2012 represented a potentially significant complementary step in terms of the activation efforts of the Portuguese PES. These efforts could be particularly important given the time of great turmoil in the labour market.

\section{Data}

This study draws on two administrative data sets, each one including rich, longitudinal monthly individual information on the population of individuals unemployed at least once over the first twelve months of the programme. The first data set was drawn from the records of the PES (IEFP) and, in its original version, includes the stock of all individuals registered as unemployed in February 2012 plus the flows of all newly registered unemployed from March 2012 up to March 2013. Most activities that were conducted by jobcentres over that period are also recorded, such as interviews, job placements, training placements, or deregistrations, including the specific Convocatórias intervention studied in this paper. The data also includes additional information such as the full dates of registration in the jobcentre and when the unemployed was subject to each intervention, as well as several background variables at the individual level, including gender, age, schooling and marital status.

The second data set was drawn from the records of the social security data agency (II, Instituto de Informática da Segurança Social). These data include information on the employment status of each individual in each month over the period under analysis, as well as all earnings, social security contributions and UBs registered. The two data sets were then merged, creating a new data set that follows individuals as they are unemployed and eventually return to the labour market (as several of those that are unemployed in February 2012) or are employed, become unemployed and eventually return to employment (as those individuals http://dre.pt/pdf1sdip/2012/02/03100/0073000732.pdf (in Portuguese). Before 2012, the range of related job subsidies included only an exemption of social security contributions (of $23,75 \%$ ) for a period of up to three years when employers hired under permanent contracts individuals that were unemployed for more than twelve months or individuals that were looking for their first job. This new ALMP offered more generous support, of up to $60 \%$ of the monthly salary for up to six months, and covered fixed-term contracts, a by far more prevalent contract type in outflows from unemployment. 
that are first unemployed in some point from March 2012).

The merged data set contains one observation for each individual in each month from February to December 2012. From this data set, we eliminate some individuals or observations to obtain the final sample which we use to estimate our results. First, given that the Convocatórias programme was targeted at subsidised unemployed, we only keep in the sample individuals that have been enrolled in the PES and have received regular UB at least once during the reference period. We also exclude individuals whose potential maximum UB duration is shorter than twelve months, because, as UB potential duration influences transitions to employment, they may not be comparable to those with longer potential UB duration.

As mentioned previously, Convocatórias has two eligibility criteria: UBRs who are 45 years old or older and UBRs unemployed for at least six months. Because we want to focus exclusively on those eligible through UB duration, we exclude from our sample all UBRs that are at least 45 years old (these UBRs would be automatically eligible as soon as the programme is introduced, implying the need for a different identification strategy). Moreover, we wish to focus on UBRs whose maximum UB duration is not smaller neither much larger than the threshold level of six months, given our regression discontinuity approach. We therefore exclude all observations whose UB duration is greater than twelve months. Finally, given our focus on transitions out of unemployment, namely of those subject to the programme, we consider in our final sample only the observations in which the individual is unemployed, keeping a record of the timing of a possible transition to employment.

As we can see in Table 1, which describes the participants in the programme by month of their intervention, Convocatórias started in March 2012, with around 7,500 unemployed having participated in that month. Participation increased to around 16,000 in April and May and then started decreasing, given the decrease in new eligibles to the programme. Of the approximately 80,000 unemployed that participate in Convocatórias, around 30,000 participate in ALMPs or in collective sessions on job search techniques.

The table also indicates the average characteristics of participants by month of participation. It can be seen that age and marital status are relatively constant, while the percentage of women varies across the period but is always between 40 and $50 \%$. Average schooling years are relatively lower for those that participate in the first two months, while they remain fairly stable in the last months of the period, which is driven by some priority attributed to the 
low-skilled unemployed that are eligible. We also find that the distribution of participants by region is very unequal, given the different sizes of each region: 22,317 in the North, 10,814 in the Centre, 42,693 in the Lisbon and Tagus Valley, and 1,802 and 3,214 in the Alentejo and the Algarve, respectively.

In the end, our sample contains 105,595 different individuals and 611,061 (individualmonth) observations. 25,241 individuals (24\%) are subject to the programme. The difference between this figure and the 80,000 reported above is driven by our focus on the stream of the programme targeted at the unemployed on UB for at least six months (and aged 44 or less) and the related elimination of those with an UB duration of more than 12 months. As this programme was targeted initially at the stock of unemployed, many of which have UB durations of twelve months or more, this naturally leads to a smaller treatment group under analysis. Other individuals are dropped because of data issues, including those that hold different types of UBs (income support related) or exhibit several changes between employment and unemployment over the period considered.

As to the variables used, our main outcome considered is the transition from (subsidised) unemployment to employment, a dummy equal to one if an UBR becomes employed in the following month. We also consider other related outcome variables, such as transitions out of subsidised unemployment and transitions to non-subsidised unemployment. As in the main case, we assess the transition from the perspective of the month when the individual is still in a subsidised unemployment situation and conduct the analysis regarding possible changes in that situation over a one-month time window. A fourth dependent variable concerns the income of the individual over the following month. This variable can increase, for instance when an UBR takes a job that pays a salary higher than the UB, or fall, for instance when an UBR moves to non-subsidised unemployment.

The treatment variable is a dummy equal to one if the individual was treated, that is, was required to attend a meeting at a jobcentre under the context of Convocatórias, in that month. We also draw on an eligibility variable, which is a dummy indicating whether the unemployed's UB duration is six months or more. This variable will be used as an instrument for the treatment, in the context of our fuzzy RD approach (see below).

We use several explanatory variables: age; gender (a female dummy variable); marital status (married or cohabitant); nationality (foreigner); and schooling years. Other variables 
used are the potential UB duration and the daily UB amount. These indicate, respectively, the number of days of UB and the amount in euros the unemployed is entitled to at the moment they become unemployed.

Table 2 presents descriptive statistics on all the variables mentioned above on all the observations of the sample used for estimations. We find that the probability of reemployment in the following month is only $4.4 \%$, while the probability of a transition out of unemployment is $6.2 \%$ (and the probability of a transition to non-subsidised unemployment is $1.7 \%$. Average monthly income increases is of $1 \%$.

\section{The econometric model}

Our analysis of the effects of the Convocatórias programme is based on a regression discontinuity $(\mathrm{RD})$ analysis. Identification draws on the treatment discontinuity that occurs at the UB duration of six months given that the unemployed are only eligible when their UB spell hits that threshold. However, not all eligible are treated at that point.

The forcing (or running) variable, $Z_{i t}$, is the UB duration of individual $i$ at month $t$. To facilitate the interpretation of results, we center the forcing variable using instead $\widetilde{Z}_{i t}=$ $Z_{i t}-Z_{0}$, where $Z_{0}$ is the discontinuity point $\left(Z_{0}=6\right.$, in our case). The treatment status variable is $D_{i t}$, a dummy variable equal to one if individual $i$ is called to a Convocatórias jobcentre meeting. Moreover, the outcome variable is $Y_{i t}$, a dummy variable equal to one when the unemployed individual become employed in month $t+1$. Finally, $X_{i t}$ is a vector of covariates (gender, age, etc), while $S\left(Z_{i t}\right)$ is a polynomial function of the (centered) forcing variable.

As Convocatórias was implemented gradually, not every UBR participated in the programme as soon as they became eligible. Hence, the probability of treatment does not jump from zero to one at the specific UB duration threshold, $E_{i t}=1\left[\widetilde{Z}_{i t} \geq 0\right]$, as in a 'sharp' RD. Instead, the probability increases from zero to a significant positive value at the eligibility threshold - the case of a 'fuzzy' RD design. This jump is illustrated in Figure 1, which presents the percentage of the unemployed at each UB duration level that are subject to the programme (dots). The figure indicates that the probability of being treated is zero up to the threshold and then jumps to about 0.1 at that level.

The main assumption of the RD approach is that the forcing variable is continuous around 
the threshold. This assumption is not directly testable but a graphical analysis is a useful check. Figure 1 also indicates the number of observations for each value of the forcing variable (solid line): unlike in the case of treatment, we find evidence in favour of the continuity of the forcing variable around the threshold.

It is important to note that the profiles of the unemployed present will typically be different in each level of unemployment duration, in terms of both observable and unobservable characteristics. This will drive the duration dependence commonly observed in outflows, from some combination of direct effects from unemployment duration (in terms of reduced human capital, for instance) and composition effects (greater prevalence of individuals that are less likely to find jobs at all levels of unemployment). However, to the extent that the six-month threshold considered here is not associated with other systematic differences across the unemployed in terms of their likelihood of finding employment other than the effects of the programme, our results can be interpreted as the causal impact of Convocatórias.

More specifically, in our case, the fuzzy design is implemented econometrically in terms of two-stage least squares (2SLS), by estimating the following equation:

$$
Y_{i t}=\alpha+\beta D_{i t}+S\left(\widetilde{Z}_{i t}\right)+\delta X_{i t}+\epsilon_{i t}
$$

in which $E_{i t}$ is used as an instrument for $D_{i t}$.

Since, in the fuzzy design, the probability of being treated is no longer a deterministic function of the forcing variable, the discontinuity in the outcome variable at the threshold cannot be interpreted as an average treatment effect. Nevertheless, Hahn et al. (2001) show that it is possible to recover the treatment effect by dividing the jump in the outcome variable at the threshold by the jump in the probability of treatment, also at the threshold. The latter increase in the probability of treatment is driven by the fraction of individuals induced to be treated ('compliers'), who would not be treated in a setting without treatment. This treatment effect is a weighted local average treatment effect (weighted LATE), where the weights are the ex-ante likelihood that the individual's $Z_{i t}$ is near the threshold. 


\section{Reemployment effects}

Given the important visual component of a regression discontinuity analysis, we start this section by presenting graphical evidence of the effects of the Convocatórias programme on a number of variables regarding the programme's target group. Specifically, Figures 2, 3, 4 and 5 describe, respectively, transitions to employment, transitions out of unemployment, transitions to non-subsidised unemployment, and income levels percentage changes, the first three in proportions of the unemployed at different UB duration levels, pooled across different months over the period covered. All figures also include solid lines on either side of the threshold obtained from linear splines estimated, respectively, over the (centered) UB duration intervals $[-4 ; 0[$ and $[0 ; 5]$.

Figure 2 presents a downward trend in reemployment probabilities (average transitions to employment) as UB duration increases, consistent with findings of negative duration dependence observed in studies of unemployment duration. However, at the threshold UB duration, we find graphical evidence of a (discontinuous) increase in the reemployment probability, after which it resumes its downward trend, although at a flatter rate. Moreover, the gap between the predicted reemployment probability and the actual value at the threshold unemployment duration is sizable, of about 1 p.p. In the context of our regression discontinuity approach, we can interpret this discontinuous increase in the reemployment probability as a treatment effect, especially after adjusting for the fact that many eligible were not treated. We also find a very similar pattern in Figure 3, on transitions out of unemployment. The average values are higher across the range of unemployment durations given the wider coverage of outcomes (transitions to both employment and non-employment), ranging from $5 \%$ and $8 \%$, while before this range was $3 \%$ to $7 \%$, but again there is a pronounced discontinuity at the threshold duration.

On the other hand, Figure 4 shows that transitions to non-subsidised unemployment increase steadily with UB duration, although at a lower probability than transitions to employment. More important, we find virtually no discontinuity at the six-month threshold, nor any sizeable change in the slopes of the best-fit lines. Finally, Figure 5 similarly exhibits no evidence of a discontinuous change in income levels at the threshold UB duration.

We now test the robustness of the graphical evidence above estimating the model described in Section 5. In particular, we estimate 2SLS models with a linear spline, $S\left(\widetilde{Z}_{i t}\right)=\pi_{0} \widetilde{Z}_{i t}+$ 
$\pi_{1} \widetilde{Z}_{i t} D_{i t}$, using the eligibility variable $E_{i t}$ as an instrument for the treatment variable $D_{i t}$ resulting in the following second stage equation:

$$
Y_{i t}=\alpha+\beta \hat{D}_{i t}+\varphi_{0} \widetilde{Z}_{i t}+\varphi_{1} \widetilde{Z}_{i t} \hat{D}_{i t}+\delta X_{i t}+\epsilon_{i t}
$$

The key dependent variables considered, $Y_{i t}$, are, in turn, the transitions to employment (reemployment probability), out of unemployment, to non-subsidised unemployment, and the income variation in the following period. The remaining terms of the equation are the same as explained above. The coefficients on the treatment effects are the $\beta$ 's for each equation, according to the outcome variable.

Our results following the estimation of the model above are presented in Table 3 . We also present there the results from different spline specifications (across rows). The first-stage estimates are presented in the last column and are the same for all outcome variables. Each coefficient and standard error pair across the first four columns corresponds to a separate estimation of a different model in terms of the outcome variable and the polynomial function.

Turning to the analysis of the estimates, considering the first column, which focuses on our key dependent variable (transitions to employment), the results across polynomials confirm the graphical evidence in Figure 2 and supporting its general robustness. We find in all models significantly positive effects of participation in the Convocatórias programme in terms of reemployment probabilities. The magnitude of the coefficients varies from $2 \%$ (linear polynomial) to $9 \%$ (quadratic spline). These coefficients represent an increase in reemployment probabilities from $50 \%$ to $225 \%$, taking into account the outcome mean of $4.4 \%$ (see the one but last row in the table).

In terms of the remaining dependent variables, we find that the results on the transitions out of unemployment are very similar to those on the equivalent specification for transitions to employment, as predicted from the graphical evidence. In the case of transitions out of unemployment, the coefficients also range between $2 \%$ and $9 \%$. Consistently, the transitions to non-subsidised unemployment are found not to be affected by the programme, with virtually all results insignificant. Similarly, no effects are found in terms of income variation, defined as the percentage change in the sum of all UB and employment earnings.

It is also important to note that the first stage coefficients on eligibility (the instrument) are always significantly positive, at around $12 \%$, with little variability across polynomial 
functions. This latter results confirms the relevance of the eligibility status as established in the programme in terms of actual participation in Convocatórias, namely through a request that the UBR attends a jobcentre meeting.

Overall, our findings on reemployment effects can be regarded as larger than those commonly found in the literature. Out of the 15 studies in Table A.1 only Geerdsen (2006) has a similar magnitude although that programme was implemented when the unemployment rate was only $6.1 \%$. One explanation may be related to the relatively light activation efforts that had been conducted, in general, by the Portuguese PES up until the introduction of Convocatórias, especially following the large increase in the number of the unemployed and fall in vacancies over the previous years. This situation may give rise to higher than average marginal reemployment benefits even if from relatively moderate levels of activation, such as the involvement in interviews for available vacancies or one-day jobsearch training sessions, despite the poor labour market conditions.

Another related explanation concerns the 'threat' effect (Black et al. 2003). As the Convocatórias programme consists of a meeting with a caseworker, generally followed by referrals to ALMPs, some UBR may perceive participation as an increased cost of being unemployed. Those UBR may therefore increase job search and or decrease their reservation wage even before participation or soon after it begins, leading to the documented increase in transitions out of unemployment. Moreover, the programme may have prompted some targeted UBRs that were employed informally to stop collecting UB and to register their jobs with social security given the impending likelihood that they would be required to participate in training or workfare, for instance. On the other hand, it is important to underline that, unlike Manning (2009) and Petrongolo (2009), we find that our results on transitions out of unemployment are exclusively driven by an increase in reemployment probabilities and not by an increase in transitions to non-subsidised unemployment.

A final explanation for our large positive effects is based on the theoretical discussion in van den Berg \& van der Klaauw (2006). In times of macroeconomic downturns, the effects of activation programmes on transitions to employment can be larger than in times of positive and stable macroeconomic environments, under the assumption that the unemployed rely heavily on formal job search. In this case, activation programmes lead to an increase in formal search (irrespective of what happens to informal search) and, as such, can have a 
larger impact at those times, as we find in our analysis.

\subsection{Robustness checks}

Following on the main results documented above, now we present our robustness checks. We consider our benchmark linear spline specification and focus on the key outcome variable, the reemployment probability. First, we examine whether our results are affected by the exclusion of all explanatory variables, except the polynomial function on the forcing variable. This exercise can shed light on the internal validity of the RD approach (Lee \& Lemieux 2010), as individuals are assumed to be assigned to treatment and control groups irrespective of their background characteristics. Hence, if the RD approach is valid, the results should be approximately the same, whether we control for background variables or not. This is indeed what we find in our case: the benchmark coefficient is only slightly different when we estimate Equation 2 without including covariates (see Table 4 - last row). Similar results (available upon request) are obtained for other specifications.

We also estimate our model for different subpopulations of interest, in terms of a number of observable variables (gender, age, schooling, UB potential maximum duration and UB daily amount). The results, presented in Table 4 , indicate the same qualitative findings as before: the coefficients range between $2 \%$ and $10 \%$, with above average effects for women and those with more than the median schooling of nine years. Moreover, we find below average effects for those entitled to more than the median UB daily amount of $€ 14.33$, with a coefficient of $3.3 \%$. This result is consistent with the theoretical effects of activation on job search: the greater the generosity of the UB, the less likely that activation will prompt a transition to employment.

Furthermore, we estimate the same linear spline model for those jobcentres that are more constrained in terms of their workloads. Specifically, we define a constrained jobcentre as one where the flow of newly-registered unemployed from March 2012 up to March 2013 at the jobcentre represents over $70 \%$ of the stock of unemployed registered in February 2012 at the same jobcentre (the median value across all jobcentres). We find below average effects in constrained jobcentres, which can be explained both by the greater workload of case workers and the more challenging local labour markets. In any case, it is important to note that, even in this subgroup, we find significant effects of $2 \%$. 
When analysing graphically the effects on a month-by-month basis, we also find similar discontinuities at the threshold. This is shown in Figures 6 and 7 , which present the results separately for each month since April 2012 until November 2012, decomposing the aggregate results from Figure 2, in such a way that each individual is observed only once in each estimation. The results are stable, except in the cases of the last two months, as we consider only jobcentre registrations up to September 2012. We also examine the means of several background, predetermined variables across the different UB durations, to check for jumps that may coincide with the actual threshold UB level. Such jumps could challenge the causal interpretation of our results even if the nature of our data, in our main estimations, would be biased against that case, given that the same individuals are observed over different values of UB duration. In any case, the results in Figure 8, concerning age, UB level, UB start date and UB maximum duration, do not support the case for jumps.

Another robustness check is based on Lee \& Card (2008), which discuss extensively RD in the context of a discrete forcing variable and suggest clustering standard errors on the values of the forcing variable when estimating Equation 2. We reestimate the treatment coefficient on reemployment probability, for all specifications of the polynomial function. We find that standard errors are always higher, causing the coefficients for the linear specification, the linear spline and the quadratic spline to become insignificant. However, for the quadratic and cubic specification, the results (available upon request) are still significant, even at the $1 \%$ significance level, with coefficients of 0.083 and 0.040 , respectively.

We also conduct an important falsification test, based on a different social security data set covering the year of 2011. This data set, also provided by II, includes longitudinal information on a sample of about 100,000 individuals over every month in 2011, covering both earnings and UB information. We use this data set to reconstruct as closely as possible the information we use in our main analysis, namely in terms of the transitions to employment at different unemployment spell durations. The results, drawing on a similar methodology as before, are presented in Figure 9. We find that, in clear contrast to the findings in Figure 2, there is no 'jump' in the transitions to employment at the UB duration of six months. On the other hand, the downward pattern in such transitions is particularly similar to the one obtained for the 2012 main results. We interpret this contrast between 2011 (when the programme was not in operation) and 2012 (when it was), as additional supportive evidence of a causal impact of 
the programme in terms of transitions to employment.

In an additional check, again based on an alternative data set, we examine the labour force statistics compiled by Statistics Portugal (INE). In particular, we focused on the transitions to employment of the unemployed with more or less than six months of unemployment duration before and after the Convocatórias programme was in force, in the spirit of a difference-indifferences analysis. We assumed all eligible unemployed were treated and imposed the same data restrictions as those of our main analysis. We found positive results (available upon request), of a similar magnitude as our main findings, although not statistically significant. We take this evidence to be supportive of our benchmark results.

Finally, we also examined the effects of Convocatórias along a subset of the 45 year-old group, namely by drawing on the unemployed that are 44 years and seven months old up to (but excluding) 45 years old in March 2012. These individuals become eligible in the month of their 45th birthday, in the same way as the main subset considered in this paper when the latter are unemployed for six months. Again we found positive results (available upon request), of a similar magnitude as our main findings, and statistically significant, despite the much smaller sample size. The graphical evidence is presented in Figure 10, indicating again a substantial jump in transitions to employment at the threshold age.

\section{$7 \quad$ Substitution effects}

Having established that the programme had important reemployment effects, we now turn to our analysis of substitution effects (also commonly referred to by displacement or general equilibrium effects). By such effects we refer to the extent to which the gains in employment transitions for the unemployed targeted by the programme were obtained, at least partly, from fewer transitions amongst non-eligible unemployed. Empirical evidence on this matter is not conclusive, as indicated in Section 2. Indeed, the two studies we review Blundell et al. (2004), Crépon et al. (2013) present opposite evidence of displacement effects in their analysis of programmes in the UK and France, respectively, the latter case (of significant effects) in the context of a weak labour market.

We contribute a new approach to the analysis of this question, based on access to data covering all the unemployed registered with a PES in a country and their transitions, namely out of unemployment, at a monthly frequency. In particular, we examine the extent to which 
jobcentres and months in which there is a higher level of transitions to employment amongst the Convocatórias target groups also exhibit lower levels of transitions to employment amongst the non-eligible unemployed. Should displacement effects be relevant, the two flows would be negatively related. Additionally, in order to obtain causal evidence that is not affected by shocks that simultaneously increase (or decrease) outflows of the two groups of unemployed, we conduct our analysis using an IV approach.

Specifically, we instrument the outflows amongst the targeted unemployed (in a given jobcentre and month) using the number of requests to attend meetings issued under the programme and the stock of targeted unemployed (again in a given jobcentre and month). The first instrument will explain the number of outflows of the target unemployed, given the evidence above about the reemployment effects of the programme. Moreover, this instrument should have no direct effect in terms of the outflows of non-eligible unemployed, unless indirectly via any potential displacement effects. The second instrument will again explain the outflows amongst the targeted unemployed, given that the larger the stock of such unemployed individuals, the large the number of exits to be expected. Again, this instrument should have no direct effect in terms of the outflows of non-eligible unemployed. Finally, as we also control fully for the roles of jobcentre time-invariant heterogeneity and month-specific effects in driving the outflows from unemployment (amongst eligible and non-eligible unemployed individuals) variations in the stocks of the eligible and in the jobcentre meeting requirements are likely to be driven by random factors, such as 'bumps' in the distribution of individuals of certain characteristics (namely whether they reach an unemployment duration or age thresholds) or capacity issues in each given jobcentre and month.

Our empirical analysis is based on a novel data set, constructed from the same administrative information described in Section 4. We now consider all workers aged 63 or less, and not only those aged 44 or less, that have been registered in a jobcentre between February 2012 and March 2013. After computing their transitions, namely to employment, based on individual, longitudinal data, we aggregate the information in terms of 1,118 cells made up of the 86 jobcentres and their monthly observations from February 2012 until March 2013.

Table 5 presents the resulting descriptive statistics. We find an average of 245.6 transitions from unemployment to employment across all observations, of which 146.3 concern the non-UBRs and 170.6 concern all unemployed except those UBR targeted by the programme 
(unemployed for six months or more or aged 45 or above - the latter category is the one that includes those unemployed aged 45 or above that simultaneously are unemployed for six months or more). The two target groups correspond to 46.3 and 28.7 UBRs per jobcentre per month on average. Further evidence of deteriorating state of the labour market is obtained from the average number of jobcentre enrolments over the period from individuals previously employed, 299.5, and its comparison with the average of outflows (245.6). Finally, we also report descriptive statistics concerning the number of UBRs potentially targeted by Convocatórias that are present in each jobcentre in each month: averages of 1,294.1 and 1,567.6 unemployed for six months or more or aged 45 or above, respectively; and 68.1 and 64.9 individuals from each such category that are subject to the programme. The large discrepancy between the two sets of figures stems from the fact that the first two figures concern stocks of individuals, many of which are observed in more than one jobcentre-month cell, while the last two figures refer to different individuals that are required to attend jobcentre interviews each month.

Next, we present the main equation estimated in our empirical analysis:

$$
Y_{j i t}=\beta Y_{k i t}+\alpha_{i}+\lambda_{t}+\epsilon_{i t},
$$

in which $Y_{j i t}$ indicates the unemployment-to-employment outflows of non-eligible unemployed registered in jobcentre $i$ in month $t$. These can be all unemployed including the not UBRs and excluding the UBRs unemployed for six months or more and the UBRs aged 45 or above; or all unemployed that are not UBRs. $Y_{k i t}$ indicates the unemployment-to-employment outflows of eligible unemployed (UBRs unemployed for six months or more or the UBRs aged 45 or above) registered in jobcentre $i$ in month $t$. Finally, $\alpha_{i}$ is a set of (86) jobcentre fixed effects, $\lambda_{t}$ is a set of (13) month fixed effects and $\epsilon_{i t}$ is the error term.

Additionally, the first stage analysis if based on different combinations of the following four instruments: the stock of UBRs unemployed for six months or more or aged 45 or above that are registered in a month and in a jobcentre; and the stock of UBRs unemployed for six months or more or aged 45 or above that are registered in a month and in a jobcentre and are subject to requirements to visit their jobcentre under the Convocatórias programme. These four variables will have a direct impact upon the transitions of the UBRs, in one case because of a scale effect (the more UBRs unemployed for six months or more in a given jobcentre and 
month, the more such UBRs that will become employed in that same jobcentre and month) and the other because of the effect of the programme, as indicated in the results of the previous sections for the case of the UBRs unemployed for six months or more and which we assume can be extended to the case of the UBRs aged 45 or above.

Table 6 presents our findings from considering different versions of Equation 3 . When considering only the UBRs unemployed for six or more months (first row of results), we find that our two instruments are significant and have the expected positive sign. Specifically, the transitions to employment of the UBRs for six months or more increase by 4.2 individuals per month per each additional 100 that are registered in a jobcentre and by 1.2 individuals per month per each additional 100 that are required to participate in the Convocatórias programme. However, we do not find evidence of negative effects upon the transitions to employment of not eligible unemployed, both all individuals except the eligible groups or all non-UBRs. In the first case, the second-stage coefficient of transitions to employment of the unemployed for six months or more is negative but not significant (coefficient of -0.36 and standard error of 0.24$)$. In the second case, the coefficient is positive and significant.

We also estimate a different version of equation 3 , namely by allowing the transitions of the non-eligible unemployed (either all groups except the UBRs unemployed for six or more months or the UBRs aged 45 or above or only the group of unemployed not entitled to UBs) to depend on the transitions of both groups of eligible UBRs (unemployed for six months or more or aged 45 or more). Again we find the expected first-stage results, namely in terms of positive and significant coefficients of the two instruments regarding the UBRs for six months or more when explaining the transitions to employment of those unemployed. We find that the number of UBRs aged 45 or above explains the transitions to employment of those UBRs but we do not find significant effects from the number of such UBRs that are involved in Convocatórias. The latter result may suggest that the stream of the programme focused on older workers was not so effective as the stream analysed in this paper, namely in terms of short-term (following month) effects. On the other hand, we find that the stock of unemployed for six months or more has a significant negative effect upon the employment transitions of the UBRs aged 45 or above. In any case, when turning to the second-stage results, we find that none of the four coefficients is negative, and three are even significantly positive. We also conduct additional robustness checks (available upon request) based on different subsets of the 
data, additional outcome variables (including transitions from employment to unemployment) and logarithmic versions of the variables, in which we find the same qualitative results as those presented above, supporting the case of no significant displacement effects 5

Overall, we conclude that we do not find any evidence that the Convocatórias programme had any significant substitution effects. In other words, the gains in terms of reemployment effects amongst the groups of unemployed individuals targeted by the programme were not obtained at the cost of diminished transitions to employment amongst non targeted unemployed, including the large number of unemployed that are not recipient of benefits, despite the difficult situation of the labour market at the time.

\section{Conclusions}

The high levels of unemployment still observed in many countries following the 2008 financial crisis raise considerable interest on the relative merits and potential of activation measures. In fact, measures such as counselling, training, workfare, monitoring, or sanctions can play an important role not only in addressing moral hazard problems that may follow from the generous UBs provided in many countries - these measures may also promote an effective lifelong learning strategy that ensures that unemployment can become a relatively swift springboard towards new, and ideally better, jobs.

Although several earlier studies have evaluated activation programmes, this paper is, to the best of our knowledge, the first that examines an intervention of this type that was implemented during a period of high unemployment. In fact, the unemployment rate in our case is about twice as large as the average of the rates prevailing at the times of the other programmes whose evaluations we survey. We believe that, for instance from a policy perspective, it is particularly important to know what are the prospects of activation procedures implemented at such times: although they may be potentially most important during economic crises (van den Berg \& van der Klaauw 2006), those periods may also be when the impact of activation efforts are at their weakest, given the depressed levels of labour demand and greater competition for jobs (Crépon et al. 2013).

In this paper, we analyzed a large activation programme implemented in Portugal in early 2012, when unemployment reached unprecedented high levels. The programme we evaluate,

\footnotetext{
${ }^{5}$ The F-tests of excluded instruments are rejected in all specifications while the Sargan over-identification tests are also passed in the case of Panel B, although not always in the case of Panel A.
} 
Convocatórias, was based on requiring that certain groups of unemployed benefit recipients participated in monitoring and counselling meetings in jobcentres, subsequently potentially followed by an involvement of each individual in one or more active labour market measures of a more intensive nature. Exploring the marked gaps in eligibility to participation in the programme built into its structure, we implemented a fuzzy regression discontinuity analysis based on a rich, merged longitudinal administrative data sets.

Our results indicate that the increased activation efforts delivered by the programme were successful, despite the poor macroeconomic and labour market conditions at the time (and the relatively short time span of the analysis). Indeed, the estimates imply a more than doubling of the probability of reemployment for those unemployed subject to the intervention. The effects estimated are typically of at least $4 \%$, a figure that is similar to the average monthly reemployment probability over the relevant unemployment duration range.

The main findings are also found to be robust to a large number of checks, including alternative polynomial and spline structures, different subsamples of unemployed individuals, and different jobcentres. Moreover, in an important falsification test, when replicating our main analysis but using instead equivalent data for the year before the programme was introduced, we find no evidence of jumps in the reemployment probability at the relevant threshold unemployment duration. We also find no effects in terms of transitions to non-subsidised unemployment or in terms of subsequent income levels, suggesting that the programme does not have negative effects in terms of loss of social protection or poor job match quality Acemoglu \& Shimer 2000, Petrongolo 2009).

Moreover, we draw on our coverage of all the unemployed registered in jobcentres, including those not entitled to UBs, to assess the magnitude of any substitution or displacement effects. However, we find no evidence of decreased transitions to employment amongst non-eligible unemployed, even when instrumenting the outflows of the target unemployed groups using information on the number of Convocatórias interventions across jobcentres over time.

Finally, in order to address financial impact of the programme, we conduct a simple, back-of-the-envelope cost-benefit exercise, based on our estimates. We also make a number of assumptions: First, we consider that the doubling of the transition rate into employment documented in our main findings prompts a decrease by half of the remaining (on average twelve) months of subsidised unemployment. Second, we consider an average monthly UB of 
500 euros. Third, we base our estimation on a target number of 80,000 individuals subject to the intervention in 2012 alone.

According to the parameters above, we find that the programme had a positive financial impact 240 million euros in terms of its target cohort over its first year of operation alone. This estimate assumes that displacement effects are negligible, given the evidence above. This estimate also disregards the increased social security revenues that follow from any additional employment spells. In relative terms, this estimate corresponds to over $10 \%$ of the annual unemployment insurance budget and nearly $0.2 \%$ of GDP. Of course, this already sizeable estimate does not take into account the positive human capital, psychological and other difficult to measure effects from a speedier return to employment, particularly for the long-term unemployed.

\section{References}

Acemoglu, D. \& Shimer, R. (2000), 'Productivity gains from unemployment insurance', European Economic Review 44(7), 1195-1224.

Addison, J. \& Portugal, P. (2008), 'How do different entitlements to unemployment benefits affect the transitions from unemployment into employment?', Economics Letters 101(3), 206209.

Black, D., Smith, J., Berger, M. \& Noel, B. (2003), 'Is the threat of reemployment services more effective than the services themselves?', American Economic Review 93(4), 1313-1327.

Blundell, R., Costa Dias, M., Meghir, C. \& Reenen, J. (2004), 'Evaluating the employment impact of a mandatory job search program', Journal of the European Economic Association 2(4), 569-606.

Boone, J., Sadrieh, A. \& van Ours, J. (2009), 'Experiments on unemployment benefit sanctions and job search behavior', European Economic Review 53(8), 937-951.

Borland, J. \& Tseng, Y. (2007), 'Does a minimum job search requirement reduce time on unemployment payments? Evidence from the Jobseeker Diary in Australia', Industrial and Labor Relations Review 60(3), 357-378. 
Cockx, B. \& Dejemeppe, M. (2012), 'Monitoring job search effort: An evaluation based on a regression discontinuity design', Labour Economics 19(5), 729-737.

Cockx, B., Ghirelli, C. \& Van der Linden, B. (2014), 'Is it socially efficient to impose job search requirements on unemployed benefit claimants with hyperbolic preferences?', Journal of Public Economics 113, 80-95.

Crépon, B., Duflo, E., Gurgand, M., Rathelot, R. \& Zamora, P. (2013), 'Do labor market policies have displacement effects? Evidence from a clustered randomized experiment', Quarterly Journal of Economics 128(2), 531-580.

Dolton, P. \& O'Neill, D. (2002), 'The long-run effects of unemployment monitoring and worksearch programs: Experimental evidence from the United-Kingdom', Jornal of Labor Economics 20(2), 381-403.

European Union (2013), 'Council Recommendation 2013/C 120/01 of 22 April 2013 on establishing a Youth Guarantee', Official Journal of the European Union.

Geerdsen, L. (2006), 'Is there a threat effect of labour market programmes? A study of ALMP in the Danish UI system', Economic Journal 116(513), 738-750.

Graversen, B. \& van Ours, J. (2008), 'How to help unemployed find jobs quickly: Experimental evidence from a mandatory activation program', Journal of Public Economics 92(1011), 2020-2035.

Hagglund, P. (2011), 'Are there pre-programme effects of active placement efforts? Evidence from a social experiment', Economics Letters 112(1), 91-93.

Hahn, J., Todd, P. \& Van der Klaauw, W. (2001), 'Identification and estimation of treatment effects with a regression-discontinuity design', Econometrica 69(1), 201-209.

Klepinger, D., Johnson, T. \& Joesch, J. (2002), 'Effects of unemployment insurance worksearch requirements: the Maryland experiment', Industrial and Labor Relations Review $\mathbf{5 6}(1), 3-22$.

Lechner, M. \& Wunsch, C. (2009), 'Are training programs more effective when unemployment is high?', Journal of Labor Economics 27(4), 653-692. 
Lee, D. \& Card, D. (2008), 'Regression discontinuity inference with specification error', Journal of Econometrics 142(2), 655-674.

Lee, D. \& Lemieux, T. (2010), 'Regression discontinuity designs in economics', Journal of Economic Literature 48(2), 281-355.

Manning, A. (2009), 'You can't always get what you want: The impact of the UK Jobseeker's Allowance', Labour Economics 16(3), 239-250.

Martins, P. (2014a), 30,000 minimum wages: The economic effects of collective bargaining extensions, Discussion paper 8540, IZA, Bonn.

Martins, P. (2014b), Labour market reforms in Portugal, 2011-2013: An inside perspective, Working paper, Queen Mary, University of London.

McVicar, D. (2008), 'Job search monitoring intensity, unemployment exit and job entry: Quasi-experimental evidence from the UK', Labour Economics 15(6), 1451-1468.

OECD (2007), Activating the unemployed: what countries do, in 'OECD Employment Outlook', OECD, pp. 207-242.

OECD (2012), Portugal 2012, OECD economic surveys, Organisation for Economic Cooperation and Development, Paris.

OECD (2013), Activating jobseekers: Lessons from seven OECD countries, OECD employment outlook, Organisation for Economic Cooperation and Development, Paris.

Petrongolo, B. (2009), 'The long-term effects of job search requirements: Evidence from the UK JSA reform', Journal of Public Economics 93(11-12), 1234-1253.

Portugal, P. \& Addison, J. (2008), 'Six ways to leave unemployment', Scottish Journal of Political Economy 55(4), 393-419.

van den Berg, G., Kjaersgaars, L. \& Rosholm, M. (2012), 'To meet or not to meet (your case worker) - That is the question', Discussion Paper 6476, IZA, Bonn.

van den Berg, G. \& van der Klaauw, B. (2006), 'Counseling and monitoring of unemployed workers: Theory and evidence from a controlled social experiment', International Economic Review 47(3), 895-936. 
van den Berg, G., van der Klaauw, B. \& van Ours, J. (2004), 'Punitive sanctions and the transition rate from welfare to work', Journal of Labor Economics 22(1), 211-241. 
Figure 1: Probability of treatment and number of observations by (centered) unemployment benefit duration

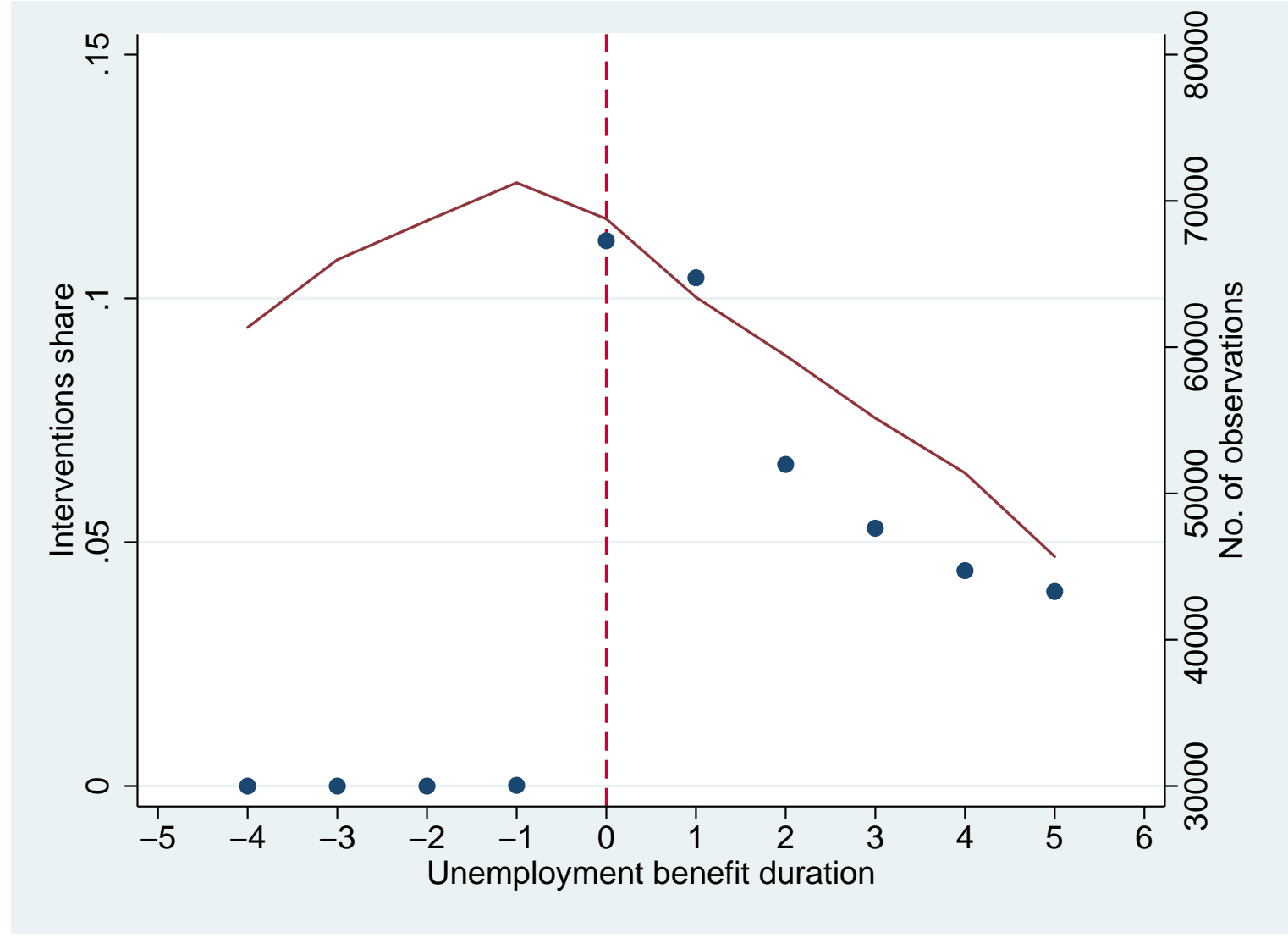

Notes: The horizontal axis indicates the (centered) values of UB duration (for instance, zero corresponds to six months of UB and six corresponds to twelve months of UB). The left vertical axis (and the blue dots) indicate the percentage of observations that are subject to a Convocatórias intervention. The right vertical axis (and the red line) indicate the total number of observations used in the pooled cross-section analysis at each specific level of the centered UB duration distribution. 
Figure 2: Reemployment probabilities by (centered) UB duration

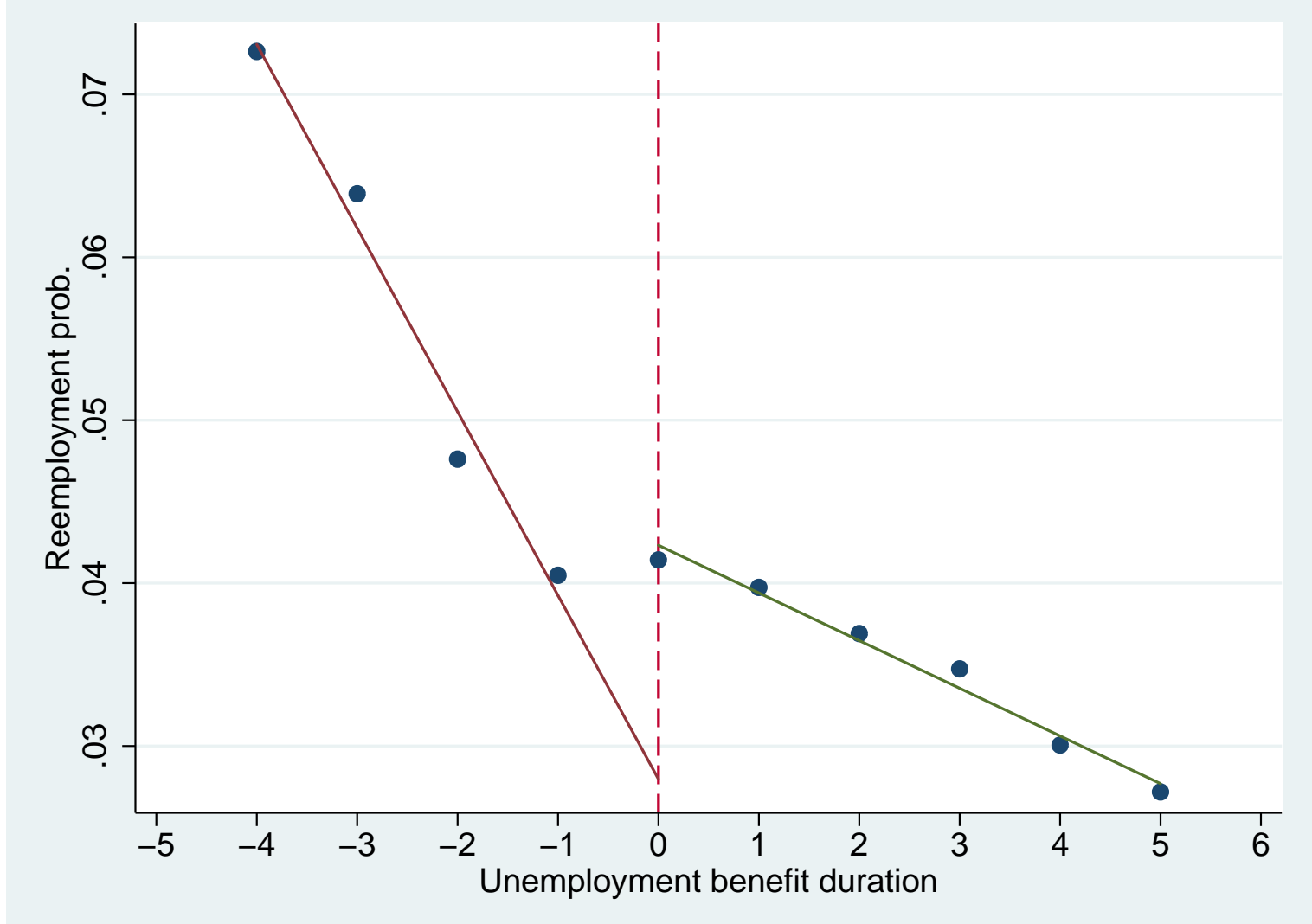

Notes: The horizontal axis indicates the (centered) values of UB duration. The vertical axis indicates the probability of reemployment in the subsequent month. The red and green lines correspond to fitted linear equations over the four and five observations at the left and right of threshold UB duration, respectively. The left line was extended towards the threshold value by computing its predicted value at that level of UB duration 
Figure 3: Unemployment exit probabilities by (centered) UB duration

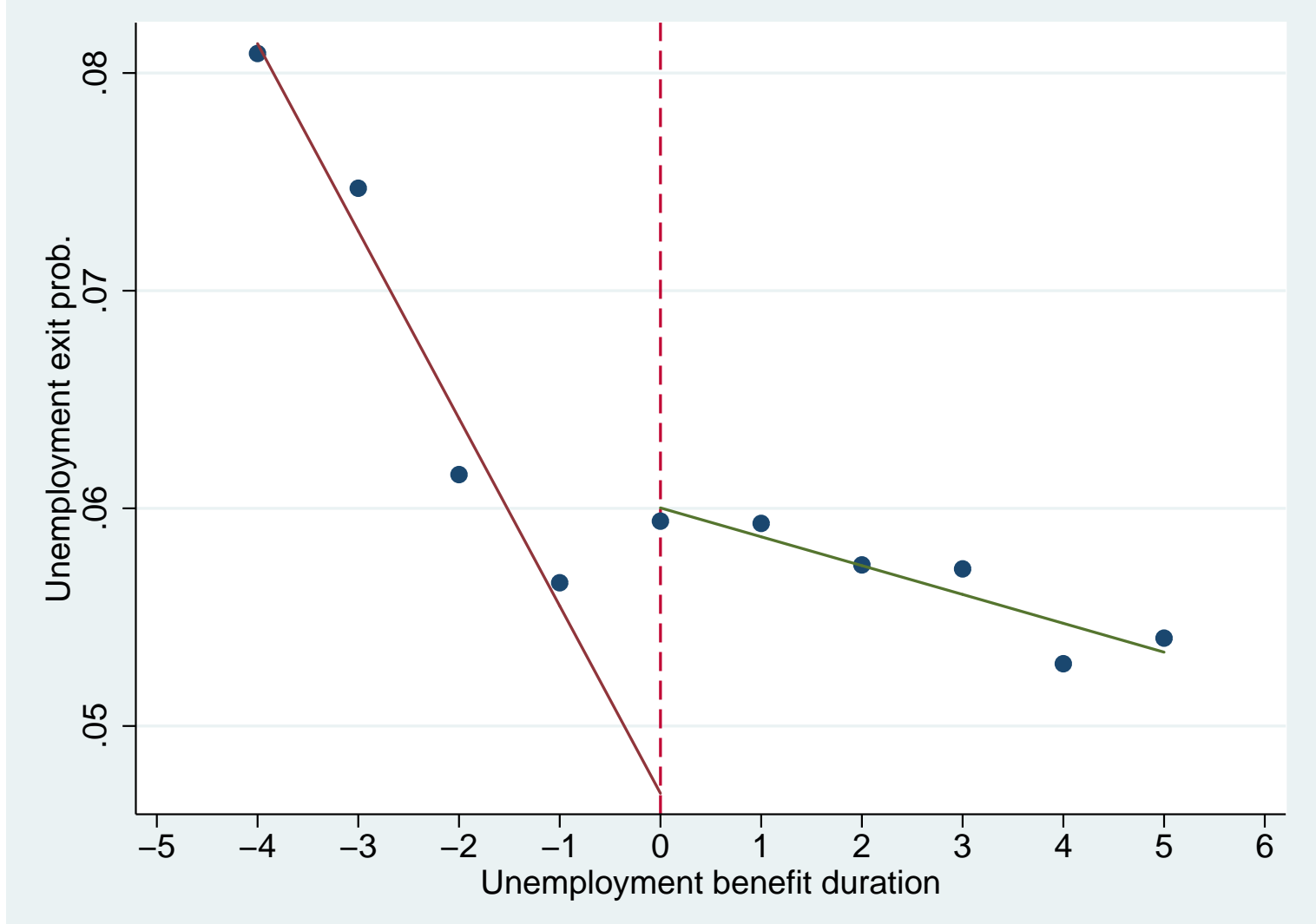

Notes: The horizontal axis indicates the (centered) values of UB duration. The vertical axis indicates the probability of unemployment exit in the subsequent month. The red and green lines correspond to fitted linear equations over the four and five observations at the left and right of threshold UB duration, respectively. The left line was extended towards the threshold value by computing its predicted value at that level of UB duration 
Figure 4: Transitions to non-subsidised unemployment by (centered) UB duration

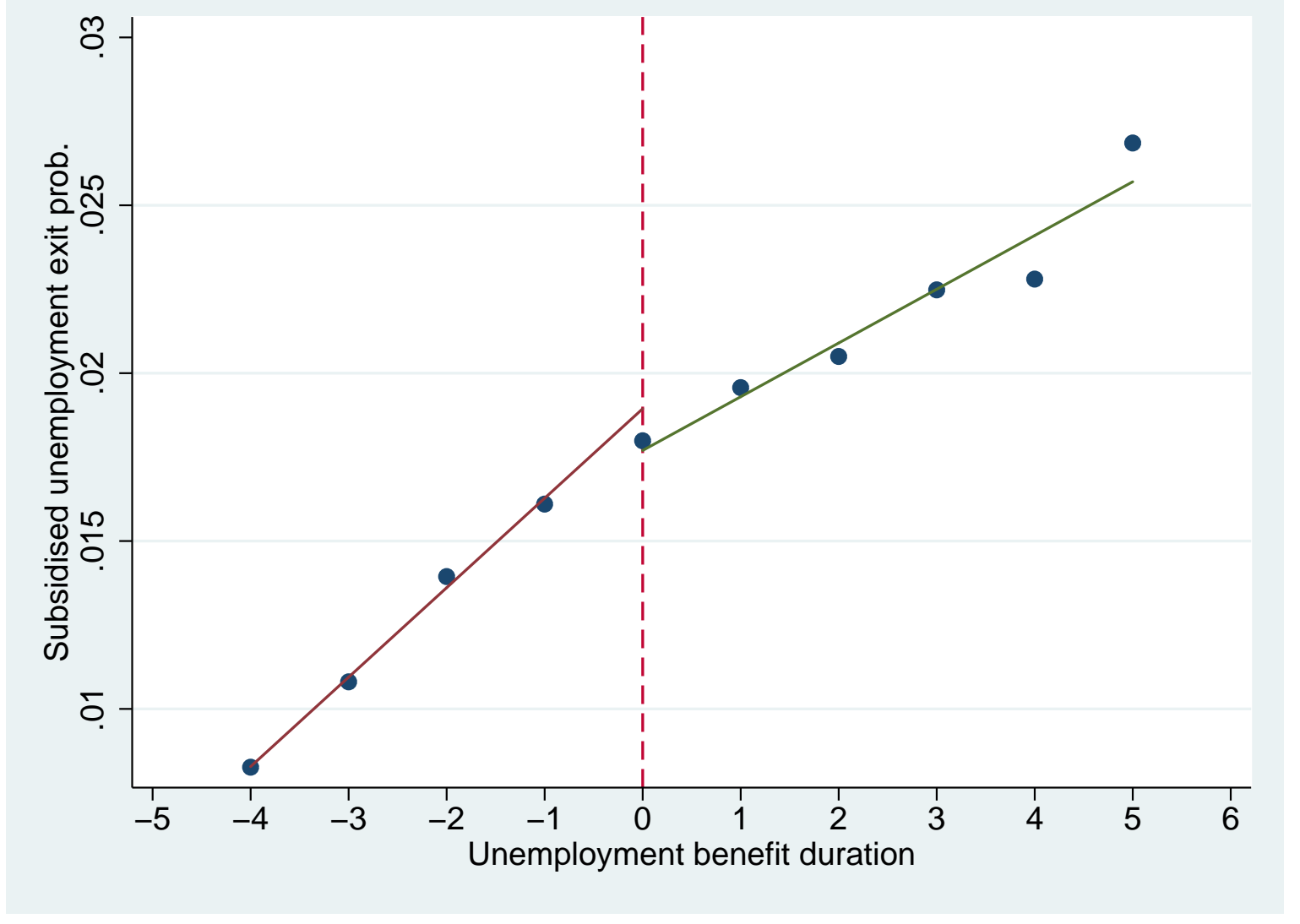

Notes: The horizontal axis indicates the (centered) values of UB duration. The vertical axis indicates the probability of transitions to non-subsidised unemployment in the subsequent month. The red and green lines correspond to fitted linear equations over the four and five observations at the left and right of threshold UB duration, respectively. The left line was extended towards the threshold value by computing its predicted value at that level of UB duration. 
Figure 5: Income level in following month by (centered) UB duration

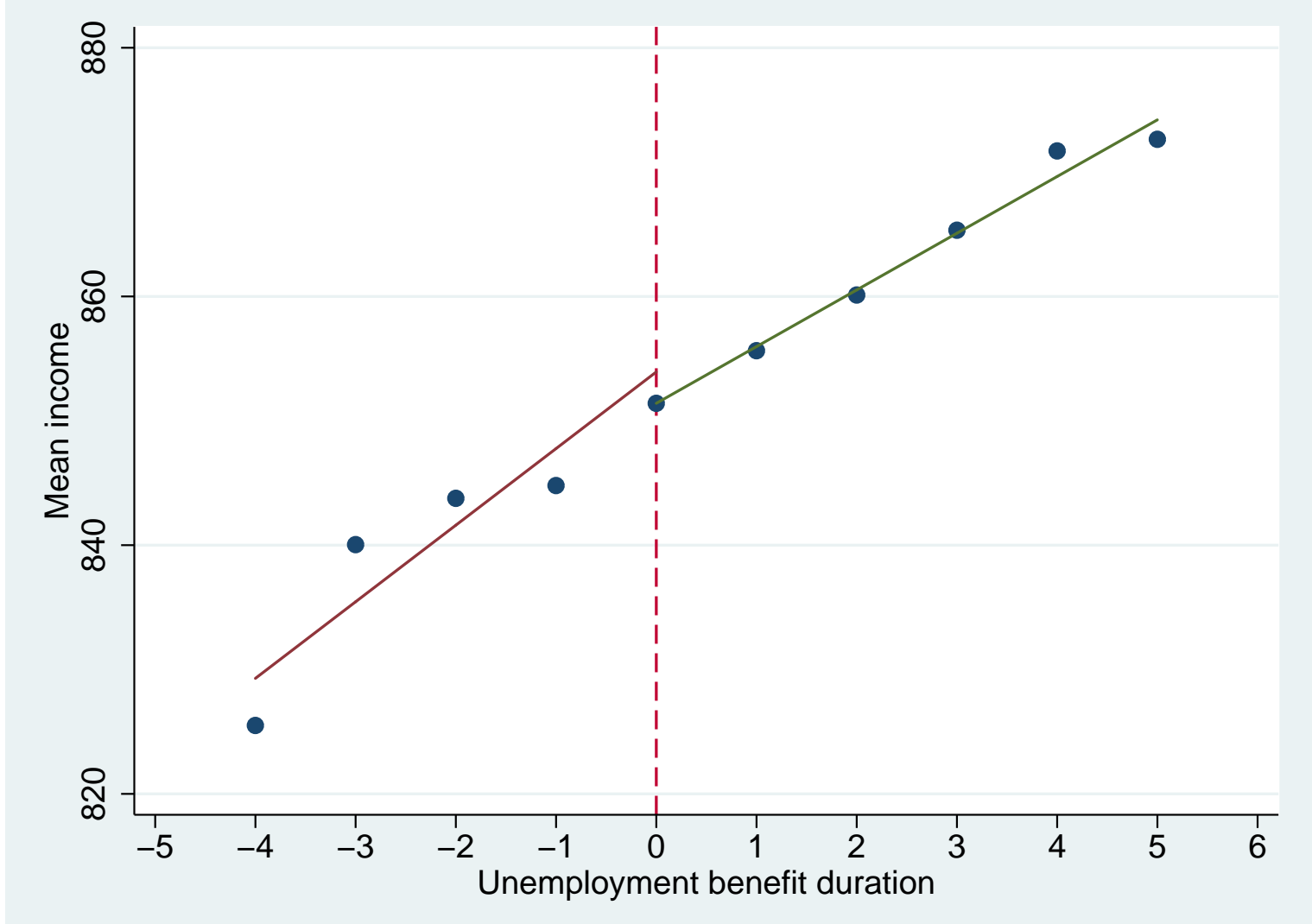

Notes: The horizontal axis indicates the (centered) values of UB duration. The vertical axis indicates the mean income percentual variation (UBs or wages) in the next month. The red and green lines correspond to fitted linear equations over the four and five observations at the left and right of threshold UB duration, respectively. The left line was extended towards the threshold value by computing its predicted value at that level of UB duration. 
Figure 6: Reemployment probabilities by (centered) UB duration and month (April to July 2012)
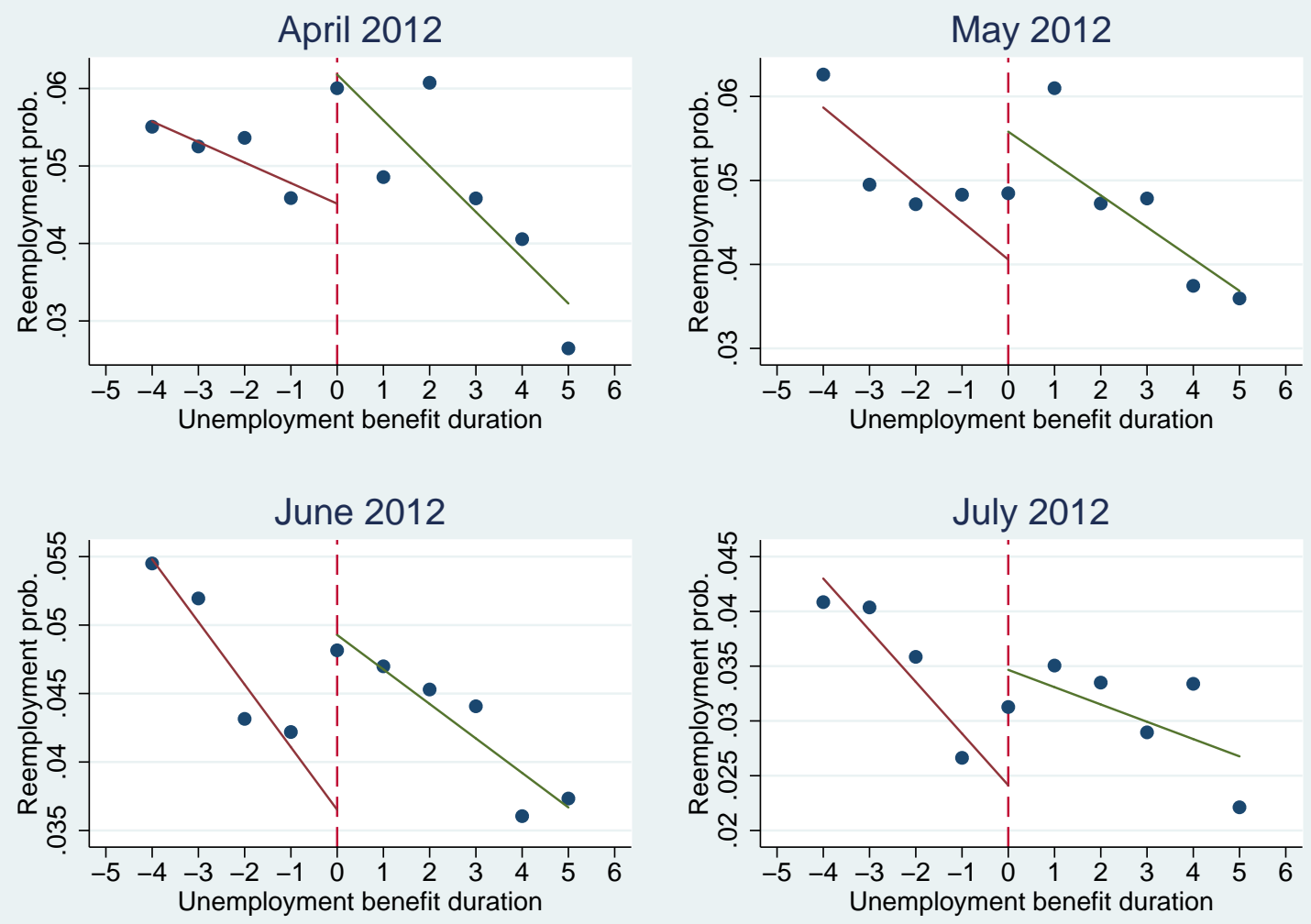

Notes: Each graph depicts results for a subsample observed only in a specific month of the period covered, from April to July 2012, respectively. The horizontal axis of each individual graph indicates the (centered) values of UB duration. The vertical axis indicates the probability of reemployment in the subsequent month. The red and green lines correspond to fitted linear equations over the four and five observations at the left and right of threshold UB duration, respectively. The left line was extended towards the threshold value by computing its predicted value at that level of UB duration. 
Figure 7: Reemployment probabilities by (centered) UB duration and month (August to November 2012)
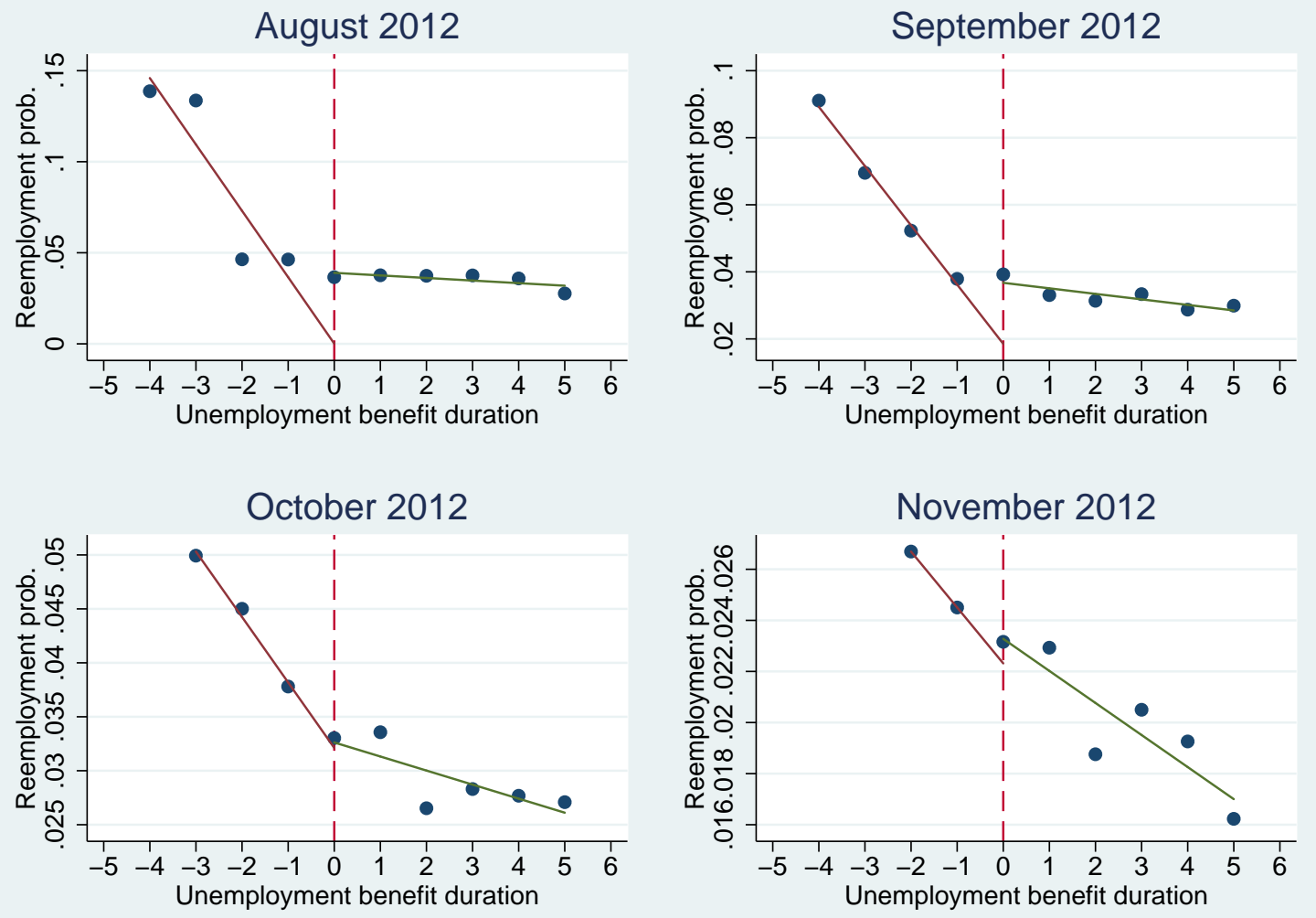

Notes: Each graph depicts results for a subsample observed only in a specific month of the period covered, from August to November 2012, respectively. The horizontal axis of each individual graph indicates the (centered) values of UB duration. The vertical axis indicates the probability of reemployment in the subsequent month. The red and green lines correspond to fitted linear equations over the four and five observations at the left and right of threshold UB duration, respectively. The left line was extended towards the threshold value by computing its predicted value at that level of UB duration. 
Figure 8: Mean values of background variables, by (centered) UB duration
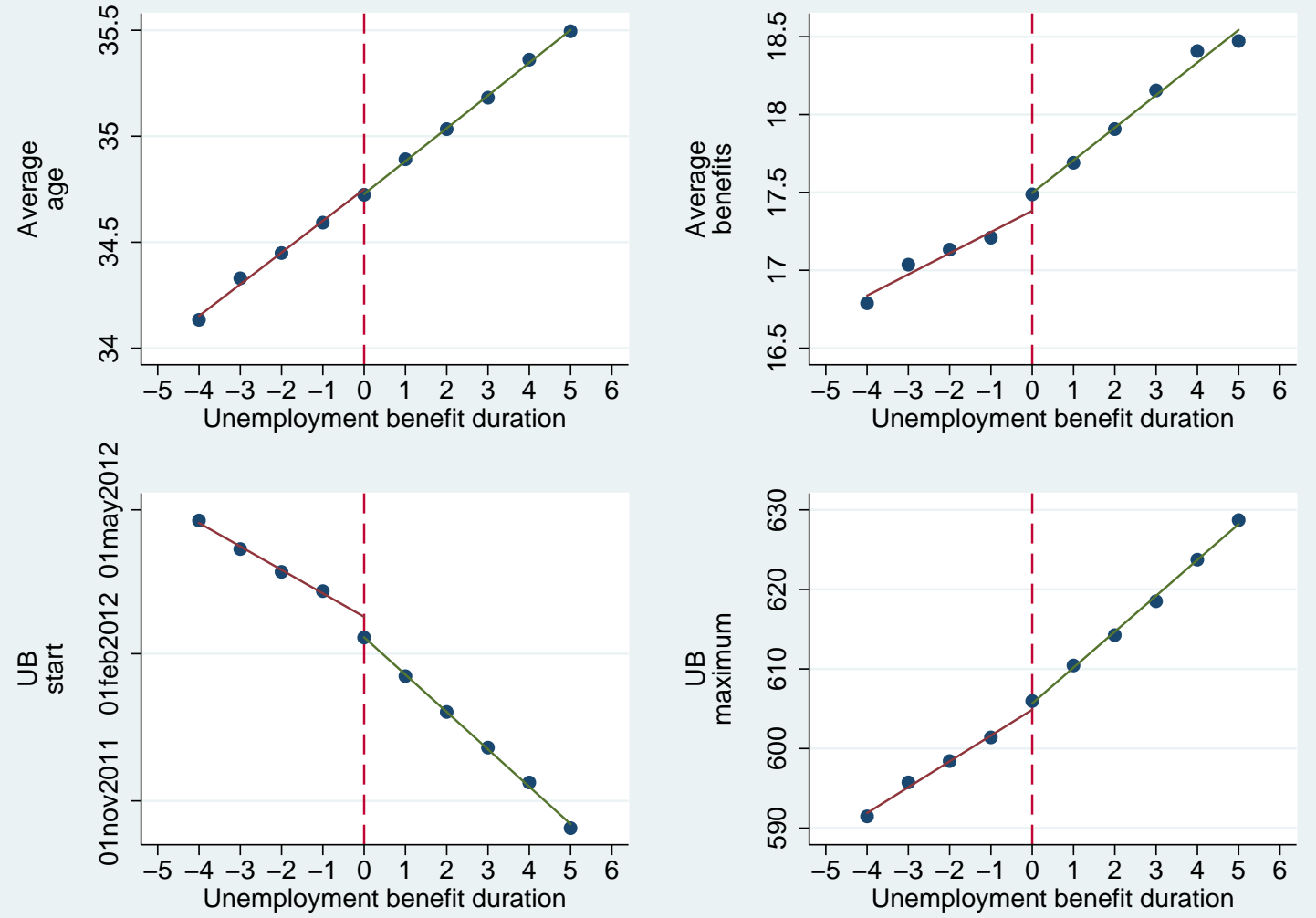

Notes: Each graph depicts results for a specific background, pre-determined variable. The horizontal axis of each individual graph indicates the (centered) values of UB duration. The red and green lines correspond to fitted linear equations over the four and five observations at the left and right of threshold UB elapsed, respectively. The left line was extended towards the threshold value by computing its predicted value at that level of UB duration. 
Figure 9: Falsification test: reemployment probabilities, by (centered) UB duration, 2011

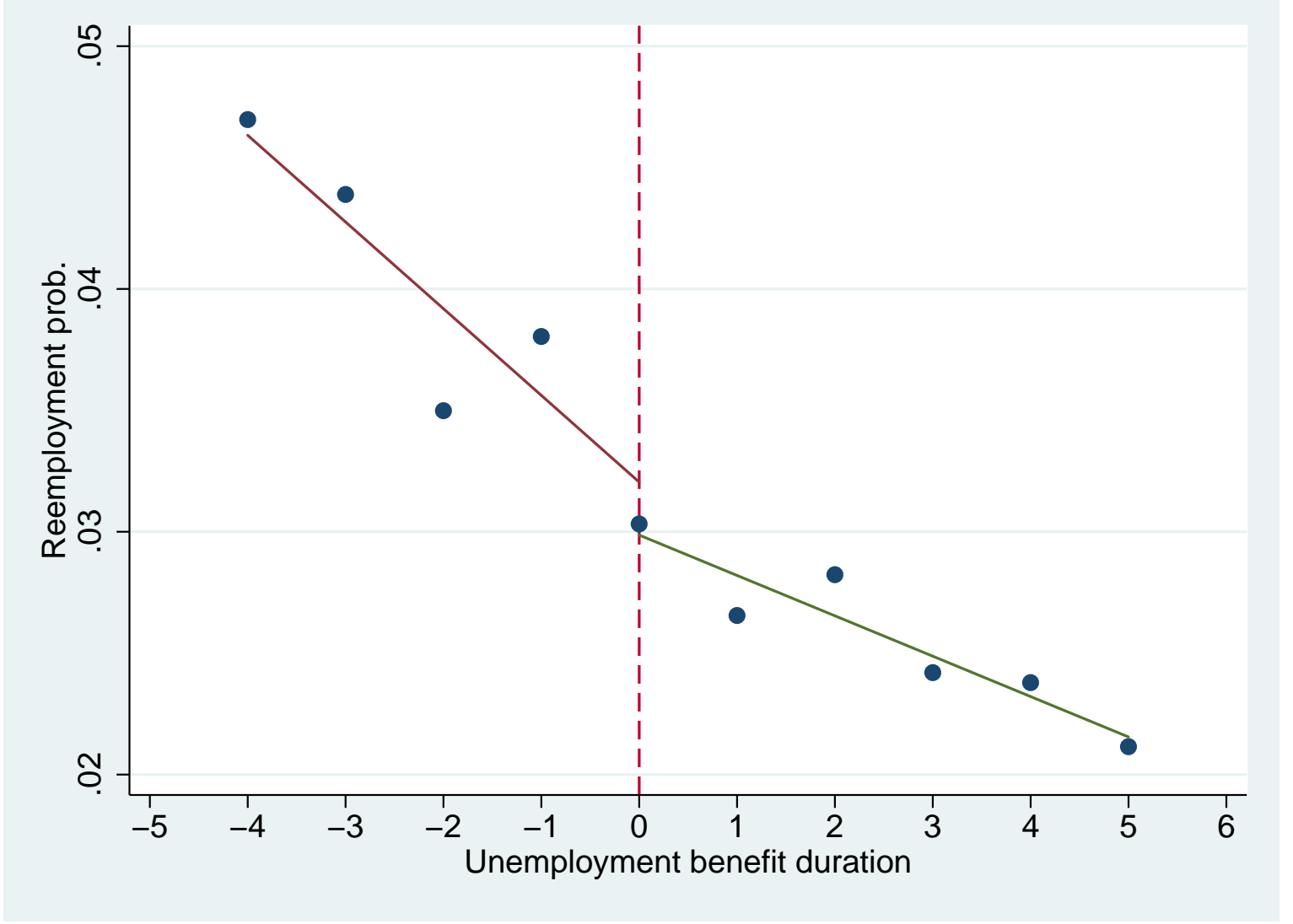

Notes: The horizontal axis indicates the (centered) values of UB duration. The vertical axis indicates the probability of reemployment in the subsequent month in 2011, the year before the Convocatórias programme. The red and green lines correspond to linear equations over the four and five observations at the left and right of threshold UB duration, respectively. The left line was extended towards the threshold value by computing its predicted value at that level of UB duration. The results are based on a different data than the one used for the main results. 
Figure 10: Reemployment probabilities by (centered) age: 45 years old age threshold

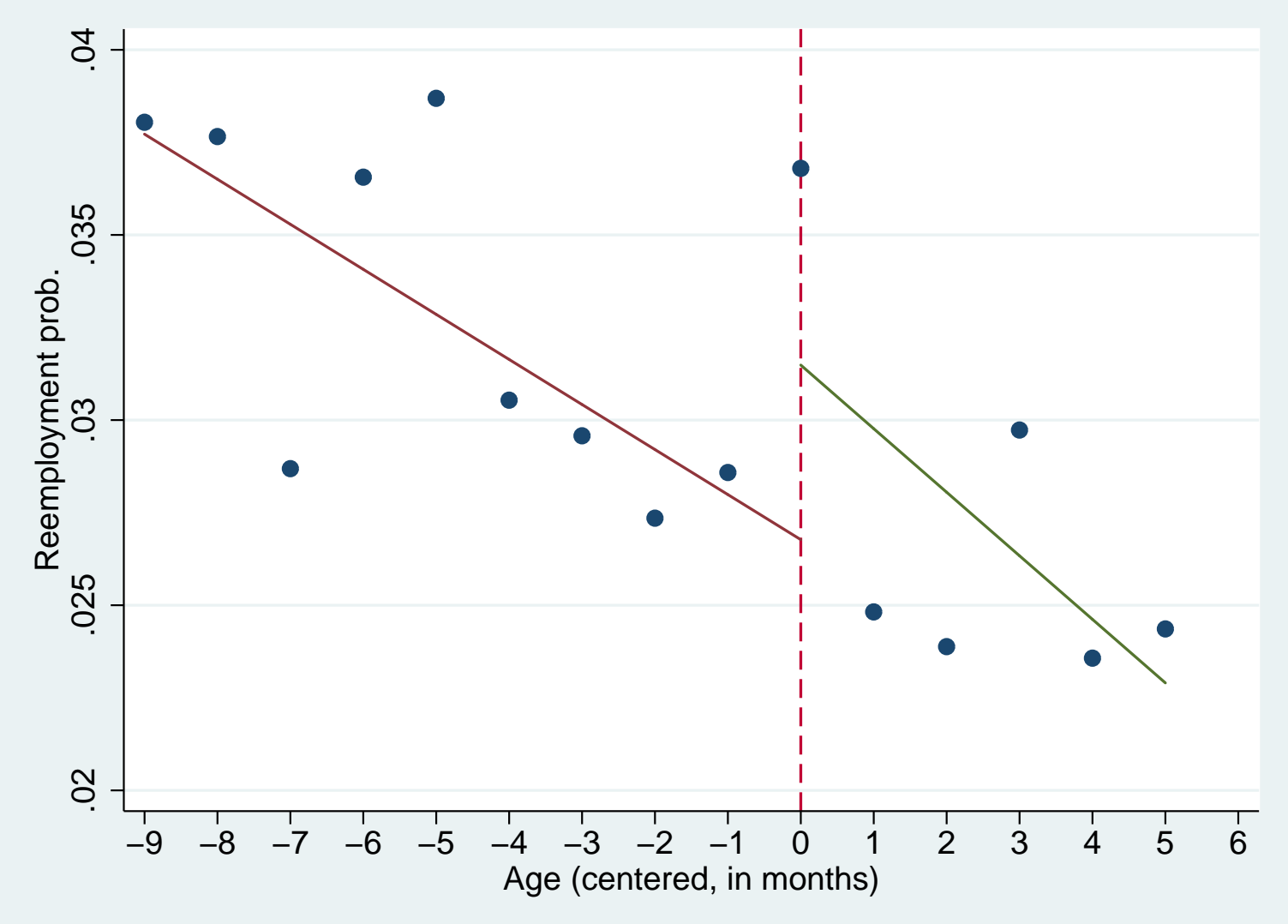

Notes: The horizontal axis indicates the (centered) values of age, in months. The vertical axis indicates the probability of reemployment in the subsequent month. The red and green lines correspond to linear equations over the observations at the left and right of threshold age, respectively. The left line was extended towards the threshold value by computing its predicted value at that age. The results are based on a different sample of data than the one used for the main results. 
Table 1: Characteristics of the unemployed, by month of participation

\begin{tabular}{|c|c|c|c|c|c|c|}
\hline \multicolumn{7}{|c|}{ Participation } \\
\hline Year & Month & Age & Female & Schooling & Married & Obs \\
\hline \multirow[t]{10}{*}{2012} & Mar & $\begin{array}{l}36.27 \\
(5.99)\end{array}$ & $\begin{array}{c}.44 \\
(.50)\end{array}$ & $\begin{array}{c}7.30 \\
(3.49)\end{array}$ & $\begin{array}{c}.47 \\
(.50)\end{array}$ & 7588 \\
\hline & Apr & $\begin{array}{l}35.87 \\
(6.21)\end{array}$ & $\begin{array}{l}.45 \\
(.50)\end{array}$ & $\begin{array}{c}7.68 \\
(3.05)\end{array}$ & $\begin{array}{l}.49 \\
(.50)\end{array}$ & 16931 \\
\hline & May & $\begin{array}{l}34.34 \\
(6.29)\end{array}$ & $\begin{array}{l}.50 \\
(.50)\end{array}$ & $\begin{array}{l}10.28 \\
(3.02)\end{array}$ & $\begin{array}{l}.45 \\
(.50)\end{array}$ & 16492 \\
\hline & Jun & $\begin{array}{l}34.41 \\
(5.98)\end{array}$ & $\begin{array}{l}.56 \\
(.50)\end{array}$ & $\begin{array}{l}11.78 \\
(3.47)\end{array}$ & $\begin{array}{l}.42 \\
(.49)\end{array}$ & 12657 \\
\hline & Jul & $\begin{array}{l}34.32 \\
(6.17)\end{array}$ & $\begin{array}{l}.53 \\
(.50)\end{array}$ & $\begin{array}{l}10.63 \\
(3.97)\end{array}$ & $\begin{array}{l}.42 \\
(.49)\end{array}$ & 6696 \\
\hline & Aug & $\begin{array}{l}34.15 \\
(6.22)\end{array}$ & $\begin{array}{l}.50 \\
(.50)\end{array}$ & $\begin{array}{c}9.70 \\
(3.22)\end{array}$ & $\begin{array}{l}.42 \\
(.49)\end{array}$ & 4921 \\
\hline & Sep & $\begin{array}{l}34.02 \\
(6.62)\end{array}$ & $\begin{array}{l}.49 \\
(.50)\end{array}$ & $\begin{array}{c}9.75 \\
(3.74)\end{array}$ & $\begin{array}{l}.42 \\
(.49)\end{array}$ & 4781 \\
\hline & Oct & $\begin{array}{l}34.54 \\
(6.22)\end{array}$ & $\begin{array}{c}.51 \\
(.50)\end{array}$ & $\begin{array}{c}9.76 \\
(3.76)\end{array}$ & $\begin{array}{l}.43 \\
(.50)\end{array}$ & 4649 \\
\hline & Nov & $\begin{array}{l}34.16 \\
(6.28)\end{array}$ & $\begin{array}{l}.51 \\
(.50)\end{array}$ & $\begin{array}{l}10.33 \\
(3.82)\end{array}$ & $\begin{array}{l}.40 \\
(.49)\end{array}$ & 2294 \\
\hline & Dec & $\begin{array}{l}34.71 \\
(5.96)\end{array}$ & $\begin{array}{l}.50 \\
(.50)\end{array}$ & $\begin{array}{c}9.67 \\
(3.97)\end{array}$ & $\begin{array}{l}.44 \\
(.50)\end{array}$ & 419 \\
\hline \multirow[t]{3}{*}{2013} & Jan & $\begin{array}{l}34.83 \\
(5.88)\end{array}$ & $\begin{array}{l}.52 \\
(.50)\end{array}$ & $\begin{array}{c}9.98 \\
(4.46)\end{array}$ & $\begin{array}{l}.51 \\
(.50)\end{array}$ & 1364 \\
\hline & Feb & $\begin{array}{l}35.15 \\
(5.88)\end{array}$ & $\begin{array}{l}.54 \\
(.50)\end{array}$ & $\begin{array}{l}10.29 \\
(3.80)\end{array}$ & $\begin{array}{l}.49 \\
(.50)\end{array}$ & 1273 \\
\hline & Mar & $\begin{array}{l}34.30 \\
(5.78)\end{array}$ & $\begin{array}{l}.55 \\
(.50)\end{array}$ & $\begin{array}{l}11.20 \\
(4.00)\end{array}$ & $\begin{array}{l}.47 \\
(.50)\end{array}$ & 775 \\
\hline Total & & $\begin{array}{l}34.85 \\
(6.23)\end{array}$ & $\begin{array}{l}.50 \\
(.50)\end{array}$ & $\begin{array}{c}9.62 \\
(3.72)\end{array}$ & $\begin{array}{l}.45 \\
(.50)\end{array}$ & 80840 \\
\hline
\end{tabular}

Notes: Statistics refer to the month when the unemployed participated in the programme and their characteristics in February 2012. Schooling measured in years. 
Table 2: Participant descriptive statistics, pooled data

\begin{tabular}{lcc}
\hline \hline & Means & S.D. \\
\hline Transition to employment & 0.044 & $(0.21)$ \\
Transition out of unemployment & 0.062 & $(0.24)$ \\
Transition to non-subsidised unemployment & 0.017 & $(0.13)$ \\
Income percentual variation & 0.010 & $(0.58)$ \\
Treatment variable & 0.041 & $(0.20)$ \\
Eligibility & 0.563 & $(0.50)$ \\
UB elapsed duration & 6.21 & $(2.76)$ \\
Age & 34.50 & $(5.66)$ \\
Female & 0.497 & $(0.50)$ \\
Married & 0.514 & $(0.50)$ \\
Foreigner & 0.059 & $(0.24)$ \\
Schooling & 10.01 & $(3.86)$ \\
Initial UB duration & 588.94 & $(142.10)$ \\
UB daily amount & 17.57 & $(6.79)$ \\
\hline Observations & 611,061 & \\
\hline \hline
\end{tabular}

Notes: Statistics based on pooled monthly data, from February 2012 to February 2013. Transitions measured in terms of following month. Eligibility is dummy variable equal to one if UB duration of six months or more. Schooling measured in years. Initial UB duration denotes maximum number of days of unemployment subsidy at beginning of spell. UB daily amount denotes euros per day of unemployment subsidy, at beginning of spell. 
Table 3: Convocatórias programme effects, different dependent variables and polynomials

\begin{tabular}{|c|c|c|c|c|c|}
\hline \multirow[b]{3}{*}{$\begin{array}{l}\text { Polynomial } \\
\text { function }\end{array}$} & \multicolumn{4}{|c|}{ Treatment effect on: } & \multirow{3}{*}{$\begin{array}{l}\text { 1st stage } \\
\text { results - } \\
\text { eligibility } \\
\text { effect }\end{array}$} \\
\hline & \multirow{2}{*}{$\begin{array}{l}\text { Reemploym't } \\
\text { probability }\end{array}$} & \multicolumn{2}{|c|}{ Transitions... } & \multirow{2}{*}{$\begin{array}{l}\text { Income } \\
\text { level }\end{array}$} & \\
\hline & & $\begin{array}{c}\text { out of } \\
\text { unemploym't }\end{array}$ & $\begin{array}{l}\text { to non-subsidy } \\
\text { unemploym't }\end{array}$ & & \\
\hline \multirow[t]{2}{*}{ Linear } & $0.021^{* * *}$ & $0.023^{* * *}$ & 0.003 & 0.007 & $0.130^{* * *}$ \\
\hline & $(0.007)$ & $(0.008)$ & $(0.004)$ & $(0.022)$ & $(0.001)$ \\
\hline \multirow[t]{2}{*}{ Quadratic } & $0.083^{* * *}$ & $0.080^{* * *}$ & -0.003 & -0.011 & $0.114^{* * *}$ \\
\hline & $(0.009)$ & $(0.010)$ & $(0.004)$ & $(0.026)$ & $(0.001)$ \\
\hline \multirow[t]{2}{*}{ Cubic } & $0.040^{* * *}$ & $0.047 * * *$ & $0.008^{* *}$ & 0.017 & $0.133^{* * *}$ \\
\hline & $(0.009)$ & $(0.010)$ & $(0.004)$ & $(0.028)$ & $(0.001)$ \\
\hline Linear & $0.041^{* * *}$ & $0.041^{* * *}$ & 0.000 & 0.002 & $0.106^{* * *}$ \\
\hline spline & $(0.009)$ & $(0.009)$ & $(0.004)$ & $(0.023)$ & $(0.001)$ \\
\hline Quadratic & $0.097^{* *}$ & $0.099^{* *}$ & 0.002 & $0.237^{* *}$ & $0.110^{* * *}$ \\
\hline spline & $(0.040)$ & $(0.041)$ & $(0.012)$ & $(0.109)$ & $(0.001)$ \\
\hline Outcome mean & 0.044 & 0.062 & 0.017 & 0.010 & - \\
\hline Obs. & 611,061 & 611,061 & 611,061 & 600,412 & - \\
\hline
\end{tabular}

Notes: Each coefficient and standard error pair is obtained from a separate 2SLS regression under a specific spline structure (indicated in the left column) and dependent variable (indicated in the top row). The last column presents the results for the first-stage results on programme eligibility term without interactions), under each polynomial function. All specifications include a large set of control variables (see main text). Standard errors in parentheses; ${ }^{*} p \leq 0.10,{ }^{* *} p \leq 0.05,{ }^{* * *} p \leq 0.01$. 
Table 4: Convocatórias programme reemployment effects, different subsamples

\begin{tabular}{lcc}
\hline \hline Subsample & Coefficient & S.E. \\
\hline Women & $0.063^{* * *}$ & $(0.013)$ \\
Over 34 years old & $0.017^{*}$ & $(0.009)$ \\
Over 35 years old & 0.012 & $(0.009)$ \\
Over 9 years of schooling & $0.102^{* * *}$ & $(0.016)$ \\
Married & $0.032^{* *}$ & $(0.013)$ \\
Over 570 days UB potential duration & $0.021^{* *}$ & $(0.009)$ \\
Over 600 days UB potential duration & 0.011 & $(0.010)$ \\
Over $€ 14.33$ UB daily amount & $0.033^{* * *}$ & $(0.011)$ \\
Constrained Jobcentres & $0.021^{* *}$ & $(0.008)$ \\
Exclusion of subsidised employment & $0.041^{* * *}$ & $(0.009)$ \\
\hline Regression excluding covariates & $0.047^{* * *}$ & $(0.008)$ \\
\hline \hline
\end{tabular}

Notes: Each coefficient and standard error pair is obtained from a separate 2SLS regression. Threshold levels correspond to sample medians (or values close to the median - 34 years of age and 570 UB days thresholds). Constrained jobcentres are jobcentres where the proportion of newly-registered unemployed is higher than $70 \%$ of the stock of unemployed in the respective centre. Standard errors in parentheses; ${ }^{*} p \leq 0.10$, ** $p \leq 0.05, * * * p \leq 0.01$ 
Table 5: Descriptive statistics, by jobcentre-month cells

\begin{tabular}{lcc}
\hline \hline & Means & S.D. \\
\hline Unemployment (U) to employment (E) transitions & 245.60 & $(205.92)$ \\
U to E transitions (except 6+ months or 45+) & 170.60 & $(144.99)$ \\
U to E transitions (non subsidised unemployed) & 146.28 & $(118.44)$ \\
U to E transitions (unemployed for 6+ months) & 46.28 & $(41.80)$ \\
U to E transitions (unemployed aged 45+) & 28.73 & $(30.11)$ \\
Employment to unemployment transitions & 299.51 & $(263.02)$ \\
Subsidised unemployed registered for 6+ months & 1294.91 & $(1073.51)$ \\
Subsidised unemployed aged 45+ & 1567.61 & $(1231.23)$ \\
Subsidised unemployed for 6+ months subject to 'convocatórias' & 68.11 & $(140.04)$ \\
Subsidised unemployed aged 45+ subject to 'convocatórias' & 64.88 & $(191.86)$ \\
\hline Observations (jobcentre-month combinations) & 1118 & \\
\hline
\end{tabular}

Notes: Statistics based on data aggregated by jobcentre and for each month, from February 2012 to February 2013. The first six rows correspond to flows (computed in each jobcentre over a month) while the last four rows correspond to the stock of individuals in a given status, again by jobcentre and month. 
Table 6: Convocatórias programme substitution effects, different dependent variables and instruments

\begin{tabular}{|c|c|c|c|c|c|c|}
\hline \multirow[b]{2}{*}{$\begin{array}{l}\text { Transitions } \\
\text { (eligible } \\
\text { unemployed): }\end{array}$} & \multicolumn{2}{|c|}{$\begin{array}{c}\text { Dependent variables - } \\
\text { Transitions (not eligible): }\end{array}$} & \multirow[b]{2}{*}{$\begin{array}{l}\text { unemployed } \\
6+\text { months }\end{array}$} & \multicolumn{2}{|c|}{ 1st stage results } & \multirow[b]{2}{*}{$\begin{array}{c}\text { aged } 45+ \\
\text { subject to } \\
\text { 'convoc' }\end{array}$} \\
\hline & $\begin{array}{c}\mathrm{U} \text { to } \mathrm{E} \\
\text { (except } 6+ \\
\text { or } 45+\text { ) }\end{array}$ & $\begin{array}{c}\text { U to E } \\
\text { (non } \\
\text { subsidised) }\end{array}$ & & $\begin{array}{l}6+\text { months } \\
\text { subject to } \\
\text { 'convoc' }\end{array}$ & $\begin{array}{l}\text { unemployed } \\
\text { aged } 45+\end{array}$ & \\
\hline \multicolumn{7}{|c|}{ Panel A - two instruments } \\
\hline $\begin{array}{l}\mathrm{U} \text { to } \mathrm{E} \\
(6+\text { months })\end{array}$ & $\begin{array}{c}-0.361 \\
(0.240)\end{array}$ & $\begin{array}{c}0.297^{* *} \\
(0.164)\end{array}$ & $\begin{array}{c}0.042^{* * *} \\
(0.002)\end{array}$ & $\begin{array}{c}0.012^{* *} \\
(0.005)\end{array}$ & & \\
\hline \multicolumn{7}{|c|}{ Panel B - four instruments } \\
\hline $\begin{array}{l}\mathrm{U} \text { to } \mathrm{E} \\
(6+\text { months })\end{array}$ & $\begin{array}{c}0.435 \\
(0.303)\end{array}$ & $\begin{array}{c}0.694^{* * * *} \\
(0.161)\end{array}$ & $\begin{array}{c}0.039^{* * *} \\
(0.003)\end{array}$ & $\begin{array}{c}0.012^{* *} \\
(0.005)\end{array}$ & $\begin{array}{l}0.008 \\
(0.008)\end{array}$ & $\begin{array}{l}-0.003 \\
(0.003)\end{array}$ \\
\hline $\begin{array}{l}\mathrm{U} \text { to } \mathrm{E} \\
\text { (aged } 45+\text { ) }\end{array}$ & $\begin{array}{c}6.471^{* * * *} \\
(0.821)\end{array}$ & $\begin{array}{c}3.281^{* * * *} \\
(0.437)\end{array}$ & $\begin{array}{c}-0.019^{* * *} \\
(0.004)\end{array}$ & $\begin{array}{c}0.005 \\
(0.005)\end{array}$ & $\begin{array}{c}0.048^{* * * *} \\
(0.010)\end{array}$ & $\begin{array}{c}-0.002 \\
(0.004)\end{array}$ \\
\hline Jobcentre FE & $\mathrm{X}$ & $\mathrm{X}$ & $\mathrm{X}$ & $\mathrm{X}$ & $\mathrm{X}$ & $\mathrm{X}$ \\
\hline Month FE & $\mathrm{X}$ & $\mathrm{X}$ & $\mathrm{X}$ & $\mathrm{X}$ & $\mathrm{X}$ & $\mathrm{X}$ \\
\hline Outcome mean & 170.60 & 146.28 & & & & \\
\hline Obs. & 1118 & 1118 & 1118 & 1118 & 1118 & 1118 \\
\hline
\end{tabular}

Notes: Each coefficient and standard error pair under each one of the two transition columns in Panel A is obtained from a separate 2SLS regression. Each group of two coefficients and two standard errors under each one of the two transition columns in Panel B is obtained from a separate 2SLS regression. The four last columns present the results for the first-stage results, which are the same for the two outcome variables on the left. All specifications include fixed effects for each jobcentres (86 in total) and months (13). Standard errors in parentheses; ${ }^{*} p \leq 0.10,{ }^{* *} p \leq 0.05,{ }^{* * *}$ $p \leq 0.01$. 
Table A.1: Literature summary

\begin{tabular}{|c|c|c|c|c|c|c|c|}
\hline Paper & Country & Year & UR & Intervention & Outcome(s) & Meth. & Results \\
\hline $\begin{array}{ll}\text { Dolton } & \text { \& } \\
\text { O'Neill } & \\
(2002) & \end{array}$ & UK & 89 & 7.1 & $\begin{array}{l}\text { Job search coun- } \\
\text { selling interview } \\
(\text { Restart) }\end{array}$ & Unemployment rate & $\mathrm{RE}$ & $\Downarrow$ by 5 p.p. \\
\hline $\begin{array}{l}\text { Klepinger } \\
\text { et al. }(2002)\end{array}$ & US & 94 & 6.1 & $\begin{array}{l}\text { Job search monitor- } \\
\text { ing or workshop }\end{array}$ & $\begin{array}{l}\text { UB paid and num- } \\
\text { ber of weeks on UB }\end{array}$ & $\mathrm{RE}$ & $\begin{array}{l}\Downarrow \text { by } \$ 115 \text { and one } \\
\text { week }\end{array}$ \\
\hline $\begin{array}{l}\text { van den Berg } \\
\text { et al. }(2004)\end{array}$ & Netherl. & 94 & 6.2 & $\begin{array}{lr}\begin{array}{l}\text { Sanctions } \\
\text { porary }\end{array} & \text { (tem- } \\
\text { reduction) } & \\
\end{array}$ & $\begin{array}{l}\text { Welfare to } \text { work } \\
\text { transition }\end{array}$ & Dur & $\begin{array}{l}\text { 介 by } \text { more than } \\
140 \%\end{array}$ \\
\hline $\begin{array}{l}\text { Black et al. } \\
2003)\end{array}$ & US & $\begin{array}{l}94- \\
96\end{array}$ & 5.7 & $\begin{array}{l}\text { Mandatory employ- } \\
\text { ment and training } \\
\text { services }\end{array}$ & $\begin{array}{l}\text { UB paid, number of } \\
\text { weeks on UB and } \\
\text { subsequent earnings }\end{array}$ & $\mathrm{RE}$ & $\begin{array}{l}\Downarrow \text { by } \$ 143, \quad 2.2 \\
\text { weeks and } \Uparrow \quad \text { by } \\
\$ 1050, \text { respectively }\end{array}$ \\
\hline $\begin{array}{l}\text { Geerdsen } \\
2006) \\
\end{array}$ & Denmark & $\begin{array}{l}95- \\
97\end{array}$ & 6.1 & $\begin{array}{l}\text { Compulsory labour } \\
\text { market programmes }\end{array}$ & $\begin{array}{l}\text { Employment transi- } \\
\text { tions }\end{array}$ & $\mathrm{QE}$ & $\Uparrow$ by $145 \%$ \\
\hline $\begin{array}{l}\text { Manning } \\
(2009)\end{array}$ & UK & 96 & 7.9 & $\begin{array}{l}\text { Increase in job } \\
\text { search requirements } \\
\text { and administrative } \\
\text { hurdle (Jobseeker's } \\
\text { Allowance) }\end{array}$ & $\begin{array}{l}\text { Transitions out of } \\
\text { unemployment, to } \\
\text { employment and to } \\
\text { non-subsidised un- } \\
\text { employment }\end{array}$ & DID & $\begin{array}{l}\Uparrow \text { by } 6 \%, \text { no effect } \\
\text { and } \Uparrow \text { by } 6.7 \% \text {, re- } \\
\text { spectively }\end{array}$ \\
\hline $\begin{array}{l}\text { Petrongolo } \\
(2009)\end{array}$ & UK & 96 & 7.9 & $\begin{array}{l}\text { Increase in job } \\
\text { search requirements } \\
\text { and administrative } \\
\text { hurdle }(J S A)\end{array}$ & $\begin{array}{l}\text { Likelihood of a spell } \\
\text { on incapacity bene- } \\
\text { fits and of positive } \\
\text { earnings }\end{array}$ & DID & $\begin{array}{l}\Uparrow \text { by } 2.5-3 \% \text { and } \\
\Downarrow \text { by } 4-5 \% \text {, respec- } \\
\text { tively }\end{array}$ \\
\hline$\frac{\text { Borland \& }}{\text { Tseng }(2007)}$ & Australia & $\begin{array}{l}97- \\
98\end{array}$ & 8.6 & $\begin{array}{l}\text { Work-search mon- } \\
\text { itoring (JobSeeker } \\
\text { Diary) }\end{array}$ & $\begin{array}{l}\text { Out of unemploy- } \\
\text { ment transitions } \\
\text { and UB duration }\end{array}$ & $\mathrm{Ma}$ & $\begin{array}{l}\Uparrow \text { by } 5.1 \text { p.p and } \Downarrow \\
\text { by } 6 \%, \text { respectively }\end{array}$ \\
\hline $\begin{array}{l}\text { Blundell } \\
\text { et al. }(2004)\end{array}$ & UK & 98 & 6.1 & $\begin{array}{lr}\text { Job assistance } & \text { and } \\
\text { wage } & \text { subsidies } \\
(\text { New } & \text { Deal for } \\
\text { Young People }) & \end{array}$ & $\begin{array}{l}\text { Employment transi- } \\
\text { tions }\end{array}$ & DID & $\Uparrow$ by 5 p.p. \\
\hline$\frac{\text { McVicar }}{(2008)}$ & $\begin{array}{l}\text { N. Ire- } \\
\text { land }\end{array}$ & $\begin{array}{l}99- \\
05\end{array}$ & 4.5 & $\begin{array}{l}\text { Suspension of moni- } \\
\text { toring }\end{array}$ & $\begin{array}{l}\text { Transitions out of } \\
\text { unemployment, to } \\
\text { employment and } \\
\text { other benefits }\end{array}$ & $\mathrm{QE}$ & $\begin{array}{l}\Downarrow \text { by } 17 \%, 26 \% \text { and } \\
8 \% \text {, respectively }\end{array}$ \\
\hline $\begin{array}{l}\text { Hagglund } \\
(2011)\end{array}$ & Sweden & 04 & 7.4 & $\begin{array}{l}\text { Active placement } \\
\text { efforts }\end{array}$ & $\begin{array}{l}\text { Transitions out of } \\
\text { unemployment, to } \\
\text { employment and } \\
\text { other exits }\end{array}$ & $\mathrm{RE}$ & $\begin{array}{l}\Uparrow \text { by } 51 \%, 43 \% \text { and } \\
54 \% \text {, respectively }\end{array}$ \\
\hline $\begin{array}{l}\text { Cockx \& } \\
\text { Dejemeppe } \\
(2012)\end{array}$ & Belgium & $\begin{array}{l}04- \\
05\end{array}$ & 8.5 & $\begin{array}{l}\text { Monitoring of job } \\
\text { search efforts }\end{array}$ & $\begin{array}{l}\text { Transitions to em- } \\
\text { ployment, training } \\
\text { and out of labour } \\
\text { force }\end{array}$ & RDD & $\begin{array}{l}\Uparrow \text { by } 9 \text { p.p., no ef- } \\
\text { fect and no effect, } \\
\text { respectively }\end{array}$ \\
\hline $\begin{array}{l}\text { Graversen } \\
\& \text { van Ours } \\
(2008)\end{array}$ & Denmark & $\begin{array}{l}05- \\
06\end{array}$ & 4.4 & $\begin{array}{l}\text { Mandatory activa- } \\
\text { tion programme }\end{array}$ & $\begin{array}{l}\text { Transitions to em- } \\
\text { ployment }\end{array}$ & $\mathrm{RE}$ & 介 by $30 \%$ \\
\hline Crépon et al. & France & $\begin{array}{l}07- \\
08\end{array}$ & 8 & $\begin{array}{l}\text { Job placement as- } \\
\text { sistance }\end{array}$ & $\begin{array}{l}\text { Transitions to sta- } \\
\text { ble employment and } \\
\text { displacement effects }\end{array}$ & $\mathrm{RE}$ & $\begin{array}{l}\Uparrow \text { by } 11 \% \text { but at } \\
\text { expense of eligi- } \\
\text { ble non-treated in- } \\
\text { dividuals }\end{array}$ \\
\hline $\begin{array}{l}\text { Boone et al. } \\
(2009)\end{array}$ & Netherlan & & - & Benefit sanction & $\begin{array}{l}\text { Job acceptance } \\
\text { probability }\end{array}$ & $\mathrm{RE}$ & $\begin{array}{l}\Uparrow \text { from } 1.4 \text { p.p. to } \\
50 \text { p.p., depending } \\
\text { on benefit struc- } \\
\text { ture and wage of- } \\
\text { fers }\end{array}$ \\
\hline
\end{tabular}

Notes: This is a non-exhaustive summary of some of the main papers that seek to evaluate causally activation programmes. Column 3 presents the unemployment rate for the respective country and year. If the study spans multiple years, the rate is an average of the period. The unemployment data is from the Eurostat, except for Australia (Australian Bureau of Statistics). The methods are random experiment (RE), differencein-differences (DID), quasi-experiment (QE), matching (Ma) and regression discontinuity design (RDD). 
Table A.2: The diversity of activation strategies - examples from eight countries (1)

\begin{tabular}{|c|c|c|c|c|}
\hline & Belgium & Denmark & Germany & Netherlands \\
\hline \multicolumn{5}{|c|}{ Registration and benefit entitlement } \\
\hline Entitlement to benefits & Before registration & $\begin{array}{l}\text { Simultaneously } \\
\text { registration }\end{array}$ & $\begin{array}{l}\text { Simultaneously } \\
\text { registration }\end{array}$ & $\begin{array}{l}\text { Before registration, } \\
\text { retroactive to date of } \\
\text { loss of work }\end{array}$ \\
\hline $\begin{array}{l}\text { Placement efforts at } \\
\text { initial registration }\end{array}$ & Referrals to vacancies & None & Referrals to vacancies & $\begin{array}{l}\text { Assessment of work } \\
\text { readiness+referrals }\end{array}$ \\
\hline $\begin{array}{ll}\text { Detailed } \\
\text { interview }\end{array}$ & Yes, at first contact & Yes, within a month & Yes, within a fortnight & $\begin{array}{l}\text { Yes, at first con- } \\
\text { tact+profiling }\end{array}$ \\
\hline Confirmation of status & $\begin{array}{l}\text { Declarations } \\
\text { (monthly) }\end{array}$ & $\begin{array}{l}\text { Declarations } \\
\text { (monthly) }\end{array}$ & $\begin{array}{l}\text { Declaration of rele- } \\
\text { vant changes }\end{array}$ & $\begin{array}{l}\text { Declarations } \\
\text { (monthly) }\end{array}$ \\
\hline \multicolumn{5}{|c|}{ Job search requirements } \\
\hline Frequency of reporting & $\begin{array}{l}\text { Depends on age and } \\
\text { on results of previous } \\
\text { interviews }\end{array}$ & 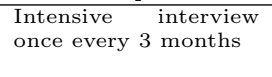 & $\begin{array}{l}\text { Intensive interview } 6 \\
\text { times a year }\end{array}$ & $\begin{array}{l}\text { Monthly (no face-to- } \\
\text { face contact) }\end{array}$ \\
\hline $\begin{array}{l}\text { Number of actions to } \\
\text { be reported }\end{array}$ & Not specified & Not specified & Not specified & 4 \\
\hline \multicolumn{5}{|c|}{ Services provided by the Public Employment Service } \\
\hline Use of direct referrals & $\begin{array}{l}1 \\
3 / \text { year/unemployed }\end{array}$ & $\begin{array}{l}1 \\
3 / \text { year/unemployed }\end{array}$ & No estimate & No estimate \\
\hline $\begin{array}{l}\text { Reports on application } \\
\text { outcomes }\end{array}$ & $\begin{array}{l}\text { Employers \& unem- } \\
\text { ployed }\end{array}$ & $\begin{array}{l}\begin{array}{l}\text { Employers } \\
\text { ployed }\end{array} \\
\end{array}$ & $\begin{array}{l}\text { Employers \& unem- } \\
\text { ployed }\end{array}$ & Employers \\
\hline $\begin{array}{l}\text { Frequency of intensive } \\
\text { interviews }\end{array}$ & $\begin{array}{l}\text { Monthly after } 2 \text { to } 9 \mathrm{M} \\
\text { unemployed }\end{array}$ & Once every 3 months & 6 per year & $\begin{array}{l}\text { Depends on counsel- } \\
\text { lor assessment, unem- } \\
\text { ployed attributes or } \\
\text { profiling }\end{array}$ \\
\hline Voluntary interviews & $20 \%$ of interview time & No information & No information & Not significant \\
\hline $\begin{array}{l}\text { Collective information } \\
\text { sessions }\end{array}$ & $\begin{array}{l}\text { Mandatory participa- } \\
\text { tion (early in spell) }\end{array}$ & No information & No information & No information \\
\hline Individual action plans & 2 to $9 \mathrm{M}$ & $\begin{array}{l}\text { Within } 9 \mathrm{M} / 6 \mathrm{M} \text { for } \\
\text { adults/youth }\end{array}$ & $\begin{array}{l}\text { Within } 1 \text { week to } 1 \mathrm{M} \\
\text { after registration }\end{array}$ & $\begin{array}{l}1 \mathrm{M} \text { for hard to place } \\
\text { clients }\end{array}$ \\
\hline \multicolumn{5}{|c|}{ Participation in ALMPs } \\
\hline $\begin{array}{l}\text { Compulsory or volun- } \\
\text { tary entry }\end{array}$ & $\begin{array}{l}\text { Compulsory only if re- } \\
\text { ferred }\end{array}$ & $\begin{array}{l}\text { Compulsory at } 9 \mathrm{M} \text { for } \\
30-60 \text { and } 6 \mathrm{M} \text { for oth- } \\
\text { ers }\end{array}$ & Voluntary & Compulsory \\
\hline $\begin{array}{l}\text { Job-search verification } \\
\text { during participation }\end{array}$ & Yes & No & No & No \\
\hline
\end{tabular}

Source: Authors' analysis based on OECD 2007). 
Table A.3: The diversity of activation strategies - examples from eight countries (2)

\begin{tabular}{|c|c|c|c|c|}
\hline & Portugal & Switzerland & United Kingdom & United States \\
\hline \multicolumn{5}{|c|}{ Registration and benefit entitlement } \\
\hline Entitlement to benefits & $\begin{array}{l}\text { Simultaneously with } \\
\text { registration }\end{array}$ & 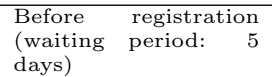 & $\begin{array}{l}\text { Simultaneously } \\
\text { registration }\end{array}$ & $\begin{array}{ll}\text { Before } & \text { registration } \\
\text { (waiting } & \text { period: } \\
\text { days) } & \end{array}$ \\
\hline $\begin{array}{l}\text { Placement efforts at } \\
\text { initial registration }\end{array}$ & Referrals to vacancies & Referrals to vacancies & Referrals to vacancies & Referrals to vacancies \\
\hline $\begin{array}{ll}\begin{array}{l}\text { Detailed } \\
\text { interview }\end{array} & \text { registration } \\
\end{array}$ & Yes, at first contact & Yes, within a fortnight & Yes, within a week & $\begin{array}{l}\begin{array}{l}\text { Yes, within } 3 \\
\text { (targeted) }\end{array} \\
\end{array}$ \\
\hline Confirmation of status & $\begin{array}{l}\text { In-person attendance } \\
\text { (fortnightly) }\end{array}$ & $\begin{array}{l}\text { In-person attendance } \\
\text { (monthly) }\end{array}$ & $\begin{array}{l}\text { In-person attendance } \\
\text { (fortnightly) }\end{array}$ & $\begin{array}{l}\text { Declarations (fort- } \\
\text { nightly) }\end{array}$ \\
\hline \multicolumn{5}{|c|}{ Job search requirements } \\
\hline Frequency of reporting & Variable & $\begin{array}{l}\text { In-person counselling } \\
\text { interview (monthly) }\end{array}$ & $\begin{array}{l}\text { In-person } \\
\begin{array}{l}\text { coun- } \\
\text { (forting }\end{array} \text { interview }\end{array}$ & $\begin{array}{l}\text { Fortnightly (no face- } \\
\text { to-face contact) }\end{array}$ \\
\hline $\begin{array}{l}\text { Number of actions to } \\
\text { be reported }\end{array}$ & Not specified & Between 4 to 10 & 10 & 10 \\
\hline \multicolumn{5}{|c|}{ Services provided by the Public Employment Service } \\
\hline Use of direct referrals & $\begin{array}{l}1 \\
3 / \text { year/unemployed }\end{array}$ & $\begin{array}{l}6 \\
8 / \text { year/unemployed }\end{array}$ & $\begin{array}{l}6 \\
8 / \text { year/unemployed }\end{array}$ & No estimate \\
\hline Reports on application & Unemployed & $\begin{array}{l}\begin{array}{l}\text { Employers \& unem- } \\
\text { ployed }\end{array} \\
\end{array}$ & Unemployed & Unemployed \\
\hline $\begin{array}{l}\text { Frequency of intensive } \\
\text { interviews }\end{array}$ & $\begin{array}{l}\text { Depends on counsel- } \\
\text { lor assessment, unem- } \\
\text { ployed attributes or } \\
\text { profiling category }\end{array}$ & Monthly & Fortnightly & $\begin{array}{l}\text { Depends on counsel- } \\
\text { lor assessment, unem- } \\
\text { ployed attributes or } \\
\text { profiling category }\end{array}$ \\
\hline Voluntary interviews & No information & No information & Some & No information \\
\hline $\begin{array}{l}\text { Collective information } \\
\text { sessions }\end{array}$ & $\begin{array}{l}\text { Mandatory participa- } \\
\text { tion (early in spell) }\end{array}$ & $\begin{array}{l}\text { Mandatory participa- } \\
\text { tion (early in spell) }\end{array}$ & Non existent & $\begin{array}{lcr}\text { Targeted } & \text { to } & \text { un- } \\
\text { employed likely } & \text { to } \\
\text { exhaust benefits } & \end{array}$ \\
\hline Individual action plans & $\begin{array}{ll}\text { Within } 6 \mathrm{M} / 3 \mathrm{M} & \text { for } \\
\text { adults/youth } & \\
\end{array}$ & Within the first $3 \mathrm{M}$ & $\begin{array}{l}\text { Within } 1 \text { week to } 1 \mathrm{M} \\
\text { after registration }\end{array}$ & Rare \\
\hline \multicolumn{5}{|c|}{ Participation in ALMPs } \\
\hline $\begin{array}{l}\text { Compulsory or volun- } \\
\text { tary entry }\end{array}$ & $\begin{array}{l}\text { Compulsory only if re- } \\
\text { ferred }\end{array}$ & $\begin{array}{l}\text { Compulsory only if re- } \\
\text { ferred }\end{array}$ & $\begin{array}{l}\text { Compulsory at } 10 \mathrm{M} \\
\text { for youth and } 22 \mathrm{M} \text { for } \\
25-49\end{array}$ & Voluntary \\
\hline $\begin{array}{l}\text { Job-search verification } \\
\text { during participation }\end{array}$ & No & Yes & No & Yes \\
\hline
\end{tabular}

Source: Authors' analysis based on OECD 2007. 